\title{
Design, Synthesis and Biological Evaluation of Pyridine-Chalcone Derivatives as Novel Microtubule-Destabilizing Agents
}

Feijie $\mathrm{Xu}^{\mathrm{a}, \#}$, Wenlong $\mathrm{Li}^{\mathrm{a}}{ }^{\mathrm{a} \#}$, Wen Shuai ${ }^{\mathrm{a}}$, Limei Yang ${ }^{\mathrm{a}}$, Yi Bi ${ }^{\mathrm{b}}$, Cong Ma ${ }^{\mathrm{c}}$, Hequan Yao ${ }^{\mathrm{a}}$, Shengtao $\mathrm{Xu}^{\mathrm{a}, *}$, Zheying Zhu ${ }^{\mathrm{d}}$, Jinyi $\mathrm{Xu}^{\mathrm{a},{ }^{*}}$

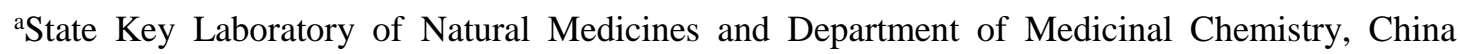
Pharmaceutical University, 24 Tong Jia Xiang, Nanjing 210009, P. R. China

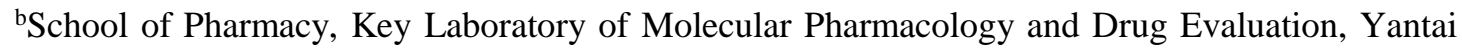
University, Yantai 264005. P. R. China

'State Key Laboratory of Chemical Biology and Drug Discovery, and Department of Applied Biology and Chemical Technology, The Hong Kong Polytechnic University, Kowloon, Hong Kon $\mathrm{g}$

${ }^{\mathrm{d} D i v i s i o n}$ of Molecular Therapeutics \& Formulation, School of Pharmacy, The University of Nottingham, University Park Campus, Nottingham NG7 2RD, U. K.

\# These authors contributed equally to this work.

\section{*Corresponding Author:}

E-mail addresses: cpuxst@163.com (S. Xu); jinyixu@china.com (J. Xu)

\begin{abstract}
Further optimization of the trimethoxyphenyl scaffold of parent chalcone compound (2a) by introducing a pyridine ring afforded a series of novel pyridine-chalcone derivatives as potential anti-tubulin agents. All the target compounds were evaluated for their antiproliferative activities. Among them, representative compound $\mathbf{1 6} \mathbf{f}$ exhibited the most potent activity with the $\mathrm{IC}_{50}$ values ranging from 0.023 to $0.045 \mu \mathrm{M}$ against a panel of cancer cell lines. Further mechanism study results demonstrated that compound 16f effectively inhibited the microtubule polymerization by binding to the colchicine site of tubulin. Moreover, cellular mechanism studies disclosed that $\mathbf{1 6 f}$ caused G2/M phase arrest, induced cell apoptosis and disrupted the intracellular microtubule network. Also, $\mathbf{1 6 f}$ reduced the cell migration and disrupted the capillary-
\end{abstract}


like tube formation of human umbilical vein endothelial cells (HUVECs). Importantly, 16f significantly inhibited tumor growth in H22 xenograft models without apparent toxicity, which was stronger than the reference compound CA-4, indicating that it is worthy to investigate $\mathbf{1 6 f}$ as a potent microtubule-destabilizing agent for cancer therapy.

Keywords: pyridine; chalcone; microtubule-destabilizing agent; colchicine site; antivascular; antitumor

\section{Introduction}

Microtubules as the key components of the cytoskeleton, are long, filamentous, tubeshaped protein polymers which are essential in all eukaryotic cells [1]. Microtubules, which are composed of $\alpha$-tubulin and $\beta$-tubulin heterodimers, play vital roles in cell proliferation, trafficking, signaling, migration, cell division and mitosis [2]. For this reason, microtubules become an important target for anticancer drugs. Microtubuleactive drugs generally bind to one of three main classes of sites on tubulin, the paclitaxel site, the vinca domain and the colchicine domain [3]. Those inhibitors that bind to the taxane or vinca alkaloid binding sites have many disadvantages such as extremely structural complexity, low aqueous solubility, multidrug resistance and dose-limiting toxicity [4]. Hence, colchicine binding site inhibitors (CBSIs) are undergoing intensive investigation in recent decades [5].

Combretastatin A-4 (1, CA-4), an excellent colchicine binding site inhibitor which was isolated from the bark of the African willow tree Combretum caffrum, displayed potent antimitotic and vascular disrupting profiles [6]. Other typical colchicine binding site inhibitors were chalcone compounds $\mathbf{2 a}$ and $\mathbf{2 b}$ which were discovered by Ducki et al. in 1998, both showing remarkable antiproliferative activities [7]. The 3,4,5trimethoxyphenyl (TMP) moiety of CA-4 was vital for its activity since the 4-methoyl group formed a critical hydrogen bond with the residue Cys241 [8-10]. Attempts to modify the TMP moiety usually led to reduced anticancer potency [11-14]. However, in 2017, Yin et al. introduced a selenium atom to replace the oxygen atom at the C-3 position of TMP to afford compound 3a, which showed improved activities both in 
vitro and in vivo compared to its parent compound isocombretastatin A-4 (IsoCA-4) [15]. Recently, Li et al. discovered a unique 3-methoxybenzo[4,5]-dioxene moiety $\mathbf{3 b}$ which exhibited improved antiproliferative activity compared with the compound bearing TMP moiety [16]. Other efforts have also been made to discover new moieties to replace the TMP moiety. In 2015, Alami and colleagues reported the discovery of compound 3c which bears a quinazoline nucleus [17], and it displayed nanomolar-level cytotoxicity against various human cancer cell. In 2017, Alami's group reported an isoCA-4 analog 3d with a quinoline moiety [18]. In 2018, Millier et al. first reported the high-resolution X-ray crystal structure of the heterocyclic-fused pyrimidine compound 3e complexed with tubulin, and the results showed that the $\mathrm{N}-1$ atom formed hydrogen bond with the residue Cys241, demonstrating that quinoline or quinazoline moieties that have $N-1$ atom might be the suitable surrogates of the traditional TMP moiety for binding to the colchicine site [19]. Meanwhile, our group also discovered a quinoline-chalcone compound $3 f$ by replacing TMP with quinoline moiety, and its antiproliferative activity was improved for 8-10 folds as well as the improvement of the solubility [20].

Nitrogenous heterocycles, such as pyridine, quinoline, pyrimidine and piperidine, are privileged building blocks in drugs [21]. Pyridine plays important roles in drug development, which can be found in a vast number of drugs like imatinib [22], telithromycin [23], indinavir [24] and acalabrutinib [25]. Even though the number of CA-4 analogs has been more than 28000 [26], compounds containing pyridine ring replacing of TMP have rarely been reported.

Recently, our group has focused on discovering and developing novel anticancer agents targeting tubulin-microtubule system, such as chalcone analogs bearing vinyl sulfone skeleton [27], 4-arylisochromenes [28], quinazolines that occupy three zones of colchicine domain [29] and quinoline-indole derivatives [30]. Inspired by Millier's work [19], we assumed that the $\mathrm{N}-1$ atom of pyridine might also form a hydrogen bond with Cys241 in the colchicine, thus pyridine might be introduced into the structures of CBSIs as an alternative ring of TMP moiety.

In this work, we continued our efforts in the modification works of the parent 
compound 2a by replacing the TMP moiety with a pyridine ring. Thus, a series of novel pyridine-chalcone derivatives were designed and synthesized (Figure 2). Herein, we would like to report the synthesis and evaluation of their antitumor activities in vitro and in vivo.

A)

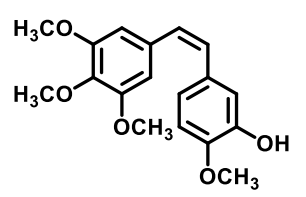

Combretastatin A-4(1, CA-4)

B)<smiles>COc1ccc(C(=O)c2cc(OC)c(OC)c(OC)c2)cc1O</smiles>

c)

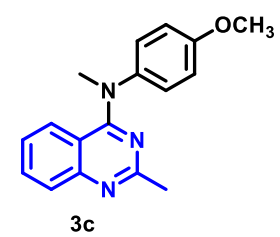

$3 c$

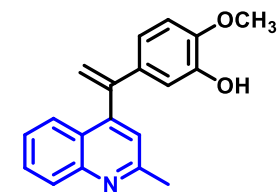

$3 d$

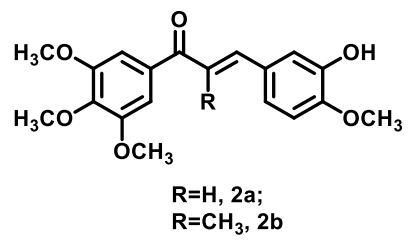<smiles>COc1cc(C(=O)c2c[nH]c(-c3c[nH]c4ccccc34)n2)cc2c1OC=CO2</smiles>

$3 \mathbf{b}$

Figure 1. A) Structures of the representative colchicine binding site inhibitors (CBSIs); B) CBSIs reported to modify TMP; C) CBSIs containing nitrogenous heterocycles in replace of TMP.

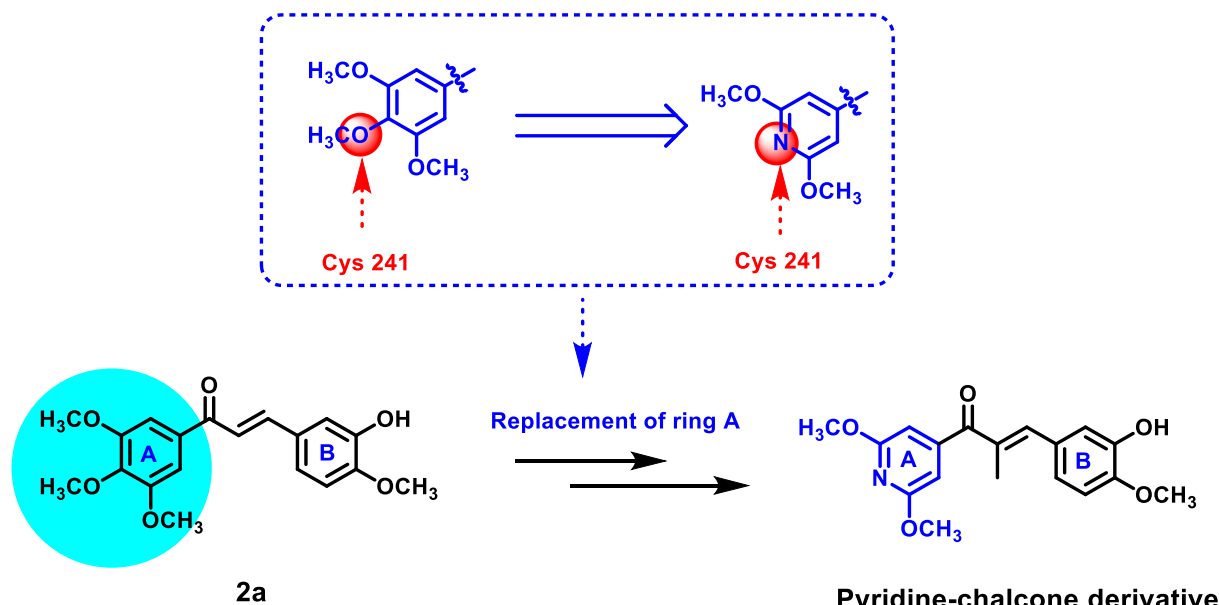

Figure 2. Design strategy of novel pyridine-chalcone derivatives.

\section{Results and discussion}




\subsection{Chemistry}

The synthetic route for the synthesis of pyridine-chalcone derivatives 15a-f and 16a$\mathbf{f}$ is outlined in Scheme 1. The intermediates $\mathbf{9 a}, \mathbf{9 b}$ and $\mathbf{1 4}$ are synthesized by two different routes. The starting material 2,6-dichloroisonicotinic acid (4) underwent nucleophilic attack by ethylmagnesium bromide $(\mathrm{EtMgBr})$ to give intermediate $\mathbf{5}$ which was then treated with 2-bromoethanol to give intermediate $\mathbf{6}$. Intermediates $\mathbf{7}$ and $\mathbf{8}$ were prepared by treating intermediate 6 with sodium methoxide in $60{ }^{\circ} \mathrm{C}$ and $100{ }^{\circ} \mathrm{C}$, respectively, followed by deprotection with hydrochloric acid to afford intermediates 9a and 9b, respectively. As for intermediate 14, the starting material 2,6dichloroisonicotinic acid (4) was first treated with $N$-methoxymethanamine to obtain intermediate 10 then underwent nucleophilic attack by methylmagnesium bromide $(\mathrm{MeMgBr})$ to give intermediate 11. Then the procedures are the same as 9a and $\mathbf{9 b}$. Subsequently, ketone 9a, 9b and $\mathbf{1 4}$ were underwent Aldol reaction with a variety of aldehydes to obtain target compounds 15a-r and 16a-f.

Scheme 1. The synthetic route for the preparation of compounds 15a-f and 16a-f ${ }^{a}$. 

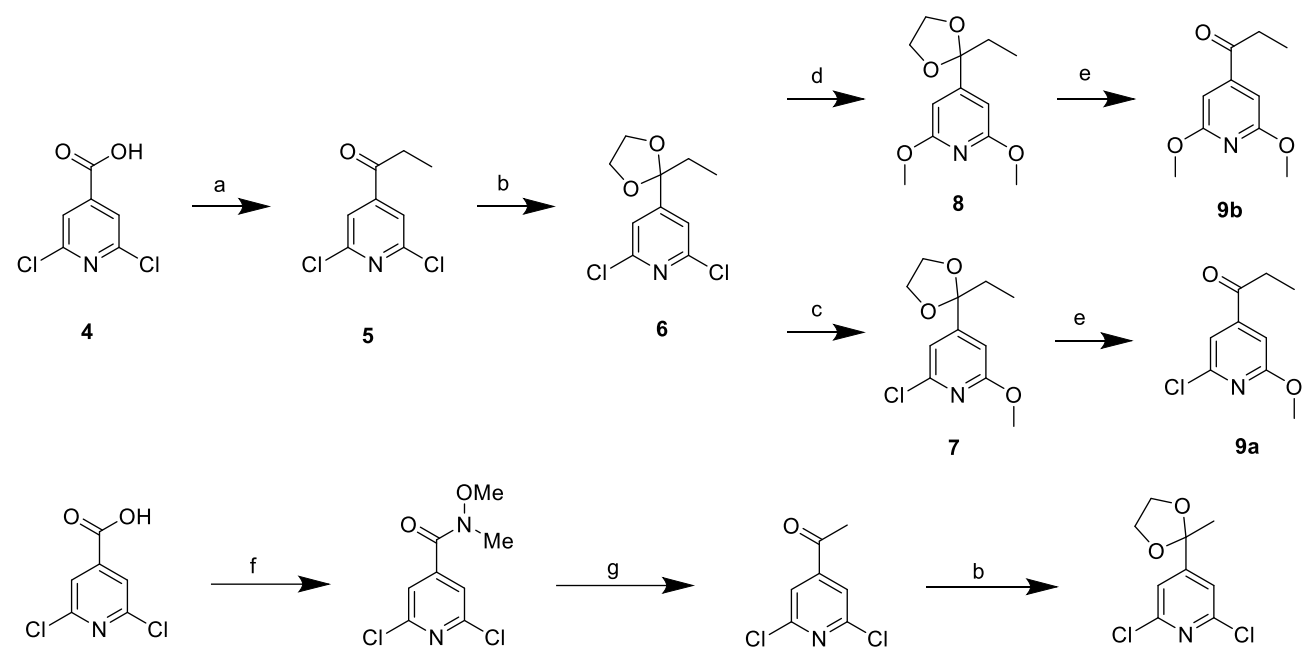

4

10

11

12

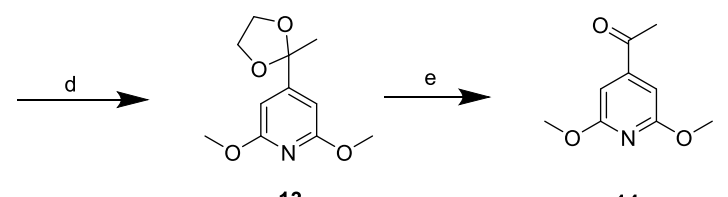

14
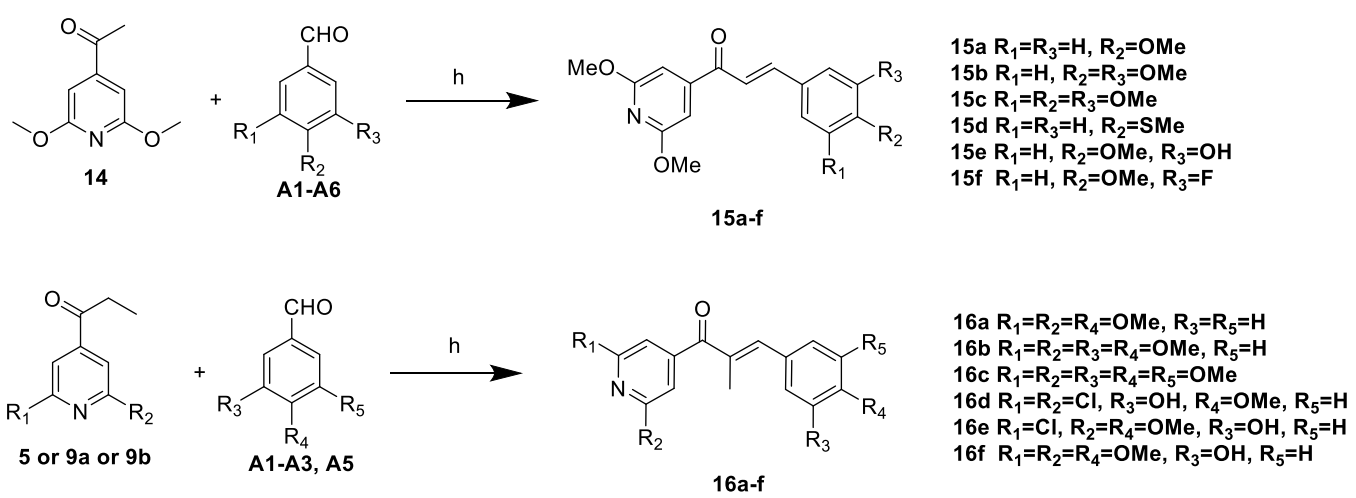

${ }^{a}$ Reagents and conditions: (a) EtMgBr, HCOOEt, THF, $\mathrm{N}_{2}$, rt, 1 h; (b) $\mathrm{BrCH}_{2} \mathrm{CH}_{2} \mathrm{OH}$, DBU, Tol, $80{ }^{\circ} \mathrm{C}$, overnight; (c) $\mathrm{MeONa}, \mathrm{MeOH}, 60{ }^{\circ} \mathrm{C}$, overnight; (d) $\mathrm{MeONa}, \mathrm{MeOH}, 100{ }^{\circ} \mathrm{C}$, overnight; (e) $1 \mathrm{M} \mathrm{HCl}, \mathrm{MeOH}, 60{ }^{\circ} \mathrm{C}, 1 \mathrm{~h}$; (f) EDCI, HOBt, $N$-methoxymethanamine, $\mathrm{Et}_{3} \mathrm{~N}, \mathrm{DCM}, \mathrm{rt}, 8 \mathrm{~h}$; (g) $\mathrm{CH}_{3} \mathrm{MgBr}$, THF, $\mathrm{N}_{2}$, rt, 1 h; (h) $\mathrm{NaOH}, \mathrm{EtOH}$, rt, 3 h.

Pyridine-indole derivatives 18a-i with different substituted positions on the indole ring were synthesized as shown in Scheme 2. Indolealdehyde derivatives were prepared by Vilsmeier-Haack reaction with DMF and phosphoryl chloride. Target compounds 18a-i were synthesized through Aldol reactions by treating indolealdehyde with ketone 9 in the presence of piperidine. 
Scheme 2. The synthetic route for the preparation of compounds 18a-i ${ }^{a}$.

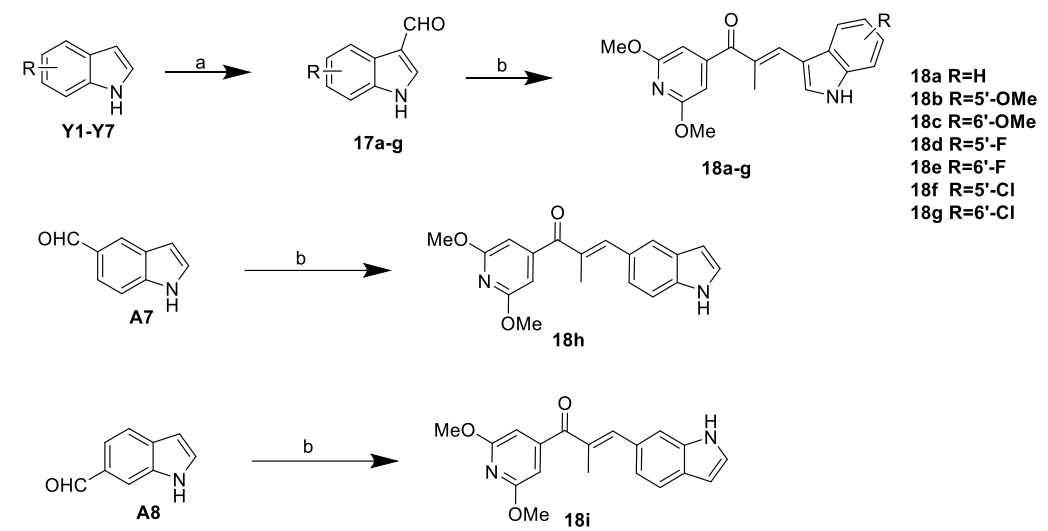

${ }^{a}$ Reagents and conditions: (a) $\mathrm{POCl}_{3}, \mathrm{DMF}, 0{ }^{\circ} \mathrm{C}, 10 \mathrm{~min}$; (b) piperidine, EtOH, reflux, overnight.

Compounds 19a-g were prepared as shown in Scheme 3. The compounds 18a and 18h was treated with methyl iodine and ethyl iodine to give the target compounds $19 \mathbf{a}$, 19b and 19h, respectively. And compound 18a was converted to $19 \mathrm{c}$ using formaldehyde with sodium hydroxide under refluxing condition. Also, compound 18a was reacted with acetyl chloride, 2-furoyl chloride and benzoyl chloride to provide the corresponding compounds 19d-f.

Scheme 3. The synthetic route for the preparation of compounds 18a-g ${ }^{a}$.

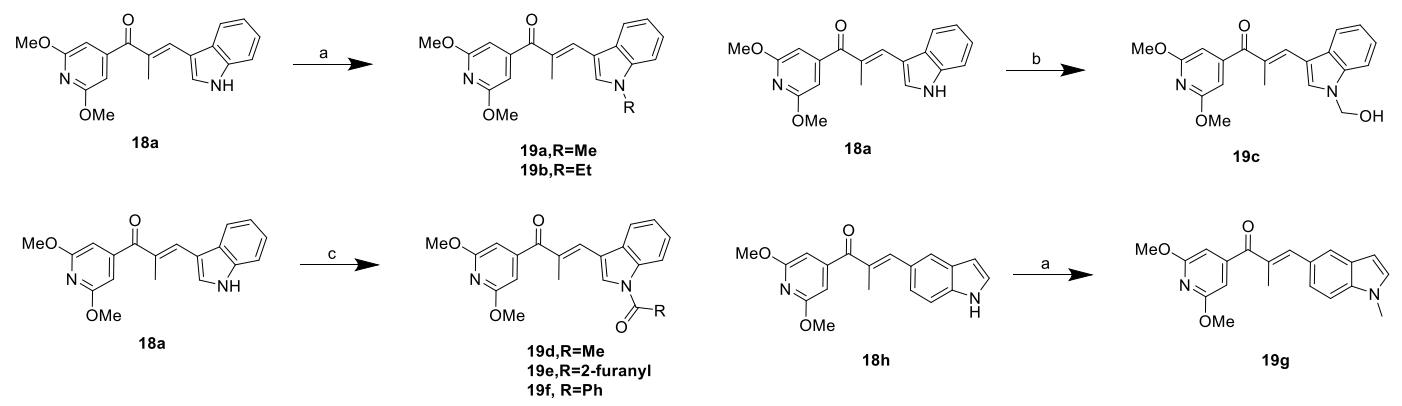

${ }^{a}$ Reagents and conditions: (a) NaH, MeI, DMF, $0{ }^{\circ} \mathrm{C}, 1$ h; (b) $\mathrm{HCHO}$, EtOH, $\mathrm{NaOH}$, reflux, 1 h; (c) acyl chloride, $\mathrm{NaOH}, \mathrm{DCM}, \mathrm{rt}, 2 \mathrm{~h}$.

\subsection{In vitro antiproliferative activity}

Target compounds 15a-f, 16a-f, 18a-i and 19a-g were evaluated for their in vitro antiproliferative efficacy against K562 cells by the MTT assays with CA-4 as the reference. As shown in Table 1, compounds with indole moieties as ring B showed favorable activity except 18b, 18f, $18 \mathrm{~h}$ and 19b. Compound $16 \mathrm{f}$ that bear 3-hydroxy- 
4-methoylphenyl moiety displayed the most potent activity with the $\mathrm{IC}_{50}$ value of 0.023 $\mu \mathrm{M}$, which was about 3-fold increase in activity when compared with the parent compound $2 \mathbf{a}\left(\mathrm{IC}_{50}=0.068 \mu \mathrm{M}\right)$, and was slightly less potent than the CA-4 $\left(\mathrm{IC}_{50}=\right.$ $0.011 \mu \mathrm{M})$. The methyl substituted at the $\alpha$-position of unsaturated carbonyl group was favorable for the improvement of activity (15a $v s \mathbf{1 6 a}, \mathbf{1 5} \mathbf{b}$ vs 16b, 15c $v s \mathbf{1 6}$ and $15 \mathbf{e}$ vs 16f), which was accordance with the results in the previous reports [7]. Besides, the exposed hydroxyl on ring B was essential for maintaining the activity (16b $v s \mathbf{1 6 f})$. Moreover, the substituents on the pyridine were also critical to the activity (16d, 16e and 16f), indicating that the electron-donating groups (EDG) were more favorable than the electron-withdraw groups (EWG). We proposed that the EDG increased the electron density of the $N-1$ of pyridine, which was beneficial to form a hydrogen bond with the critical residue Cys241. Also, the results indicated that the 3-substitued indoles were more favorable (18a $v s \mathbf{~ 1 8 h}$ and 18i), and while substituents at $\mathrm{N}-1$ of indole ring were unfavorable to activity (18a $v s$ 18b-g, 18a $v s$ 19a-f ).

Table 1. Antiproliferative activities of compounds 15a-f, 16a-f, 18a-g and 19a-g against K562 cell line ${ }^{a}$.

\begin{tabular}{|c|c|c|c|}
\hline \multirow{2}{*}{ Compd. } & IC $_{50}$ values $(\mu \mathrm{M})^{b}$ & \multirow{2}{*}{ Compd. } & \multirow{2}{*}{$\frac{\text { IC }_{50} \text { values }(\mu \mathrm{M})}{\text { K562 }}$} \\
\hline & K562 & & \\
\hline $15 \mathbf{a}$ & $>1$ & 18d & $0.352 \pm 0.004$ \\
\hline $15 b$ & $>1$ & $18 \mathrm{e}$ & $0.191 \pm 0.008$ \\
\hline $15 \mathrm{c}$ & $>1$ & $18 f$ & $>1$ \\
\hline 15d & $>1$ & $18 g$ & $0.106 \pm 0.006$ \\
\hline $15 \mathrm{e}$ & $0.983 \pm 0.013$ & $18 \mathrm{~h}$ & $>1$ \\
\hline $15 f$ & $>1$ & $18 \mathrm{i}$ & $0.142 \pm 0.036$ \\
\hline $16 \mathrm{a}$ & $0.554 \pm 0.017$ & $19 a$ & $0.700 \pm 0.023$ \\
\hline $16 \mathrm{~b}$ & $>1$ & $19 b$ & $>1$ \\
\hline $16 \mathrm{c}$ & $>1$ & $19 \mathrm{c}$ & $0.058 \pm 0.006$ \\
\hline 16d & $0.156 \pm 0.012$ & 19d & $0.086 \pm 0.008$ \\
\hline $16 e$ & $0.138 \pm 0.011$ & $19 \mathrm{e}$ & $0.060 \pm 0.003$ \\
\hline $16 f$ & $0.023 \pm 0.002$ & $19 f$ & $0.070 \pm 0.003$ \\
\hline $18 \mathbf{a}$ & $0.051 \pm 0.003$ & $19 \mathrm{~g}$ & $0.952 \pm 0.017$ \\
\hline $18 b$ & $>1$ & $\mathbf{2 a}$ & $0.068 \pm 0.002$ \\
\hline $18 \mathrm{c}$ & $0.983 \pm 0.018$ & CA-4 & $0.011 \pm 0.001$ \\
\hline
\end{tabular}

${ }^{a}$ Cells were treated with different concentrations of the compounds for $72 \mathrm{~h}$. Cell viability was measured by the 
MTT assay as described in the Experimental Section.

${ }^{b} \mathrm{IC}_{50}$ values are indicated as the mean $\pm \mathrm{SD}$ (standard error) of at least three independent experiments.

Table 2. Antiproliferative activities of representative compounds against five cancer cell lines and one normal cell line ${ }^{a}$

\begin{tabular}{ccccccc}
\hline & \multicolumn{5}{c}{ IC $_{50}$ values $(\mu \mathrm{M})^{\mathrm{b}}$} \\
\cline { 2 - 7 } Compd. & HepG2 & KB & HCT-8 & MDA-MB- & H22 & L-O2 \\
& & & & & \\
\hline 15e & $0.991 \pm 0.021$ & $1.018 \pm 0.015$ & $0.997 \pm 0.010$ & $1.128 \pm 0.011$ & $0.928 \pm 0.065$ & $4.226 \pm 0.321$ \\
16d & $0.183 \pm 0.008$ & $0.162 \pm 0.003$ & $0.177 \pm 0.005$ & $0.195 \pm 0.009$ & $0.177 \pm 0.011$ & $0.399 \pm 0.031$ \\
16e & $0.132 \pm 0.010$ & $0.147 \pm 0.012$ & $0.139 \pm 0.012$ & $0.162 \pm 0.013$ & $0.142 \pm 0.014$ & $0.768 \pm 0.054$ \\
16f & $0.047 \pm 0.002$ & $0.045 \pm 0.001$ & $0.047 \pm 0.003$ & $0.041 \pm 0.004$ & $0.043 \pm 0.002$ & $0.157 \pm 0.013$ \\
18a & $0.085 \pm 0.005$ & $0.090 \pm 0.003$ & $0.095 \pm 0.003$ & $0.079 \pm 0.002$ & $0.088 \pm 0.012$ & $0.408 \pm 0.036$ \\
18d & $0.392 \pm 0.009$ & $0.324 \pm 0.013$ & $0.335 \pm 0.011$ & $0.320 \pm 0.016$ & $0.336 \pm 0.025$ & $1.271 \pm 0.121$ \\
18e & $0.364 \pm 0.012$ & $0.421 \pm 0.022$ & $0.379 \pm 0.018$ & $0.364 \pm 0.015$ & $0.428 \pm 0.041$ & $1.102 \pm 0.104$ \\
18g & $0.124 \pm 0.012$ & $0.137 \pm 0.013$ & $0.127 \pm 0.010$ & $0.153 \pm 0.014$ & $0.127 \pm 0.013$ & $0.628 \pm 0.057$ \\
18i & $0.157 \pm 0.003$ & $0.143 \pm 0.008$ & $0.152 \pm 0.006$ & $0.148 \pm 0.005$ & $0.138 \pm 0.008$ & $0.728 \pm 0.069$ \\
19c & $0.092 \pm 0.003$ & $0.109 \pm 0.006$ & $0.121 \pm 0.009$ & $0.088 \pm 0.007$ & $0.098 \pm 0.007$ & $0.417 \pm 0.032$ \\
19e & $0.068 \pm 0.002$ & $0.072 \pm 0.006$ & $0.091 \pm 0.008$ & $0.082 \pm 0.008$ & $0.075 \pm 0.002$ & $0.338 \pm 0.031$ \\
19f & $0.093 \pm 0.001$ & $0.107 \pm 0.001$ & $0.110 \pm 0.003$ & $0.093 \pm 0.007$ & $0.108 \pm 0.011$ & $0.528 \pm 0.042$ \\
2a & $0.102 \pm 0.010$ & $0.108 \pm 0.005$ & $0.104 \pm 0.010$ & $0.102 \pm 0.009$ & $0.132 \pm 0.008$ & $0.421 \pm 0.037$ \\
CA-4 & $0.012 \pm 0.001$ & $0.011 \pm 0.002$ & $0.010 \pm 0.001$ & $0.010 \pm 0.001$ & $0.008 \pm 0.001$ & $0.095 \pm 0.011$ \\
\hline
\end{tabular}

${ }^{a}$ Cells were treated with different concentrations of the compounds for $72 \mathrm{~h}$. Cell viability was measured by the MTT assay as described in the Experimental Section.

${ }^{\mathrm{b}} \mathrm{IC}_{50}$ values are indicated as the mean $\pm \mathrm{SD}$ (standard error) of at least three independent experiments.

In consideration of the prominent antiproliferative activities of the newly pyridinechalcone derivatives against K562 cells, we tend to further evaluate the biological functions against more cancer cell lines. Human hepatocellular carcinoma (HepG2), epidermoid carcinoma of the nasopharynx (KB), human ileocecal cancer cells (HCT-8) human breast cancer cells (MDA-MB-231), and hepatoma 22 cells (H22) were selected for the further evaluation of activity. In addition, one normal non-cancerous cell line human normal liver cells (L-O2) - was chosen to evaluate the toxicity of these compounds. The cytotoxic data of representative compounds against these four cancer 
cell lines were shown in Table 2, which showed that all these chosen compounds displayed potent activities against these four cancer cell lines. Moreover, the structure activity relationships (SARs) were similar to their performances in K562 assays. Also, the K562 cell was the most sensitive cell line among five cancer cell lines tested, and the most active compound $\mathbf{1 6}$ exhibited remarkable activity with $\mathrm{IC}_{50}$ values ranging from 0.023 to $0.047 \mu \mathrm{M}$, which was about 3-fold improvement of activity when compared with the parent compound 2a. The SARs of synthesized compounds were summarized in Figure 3.

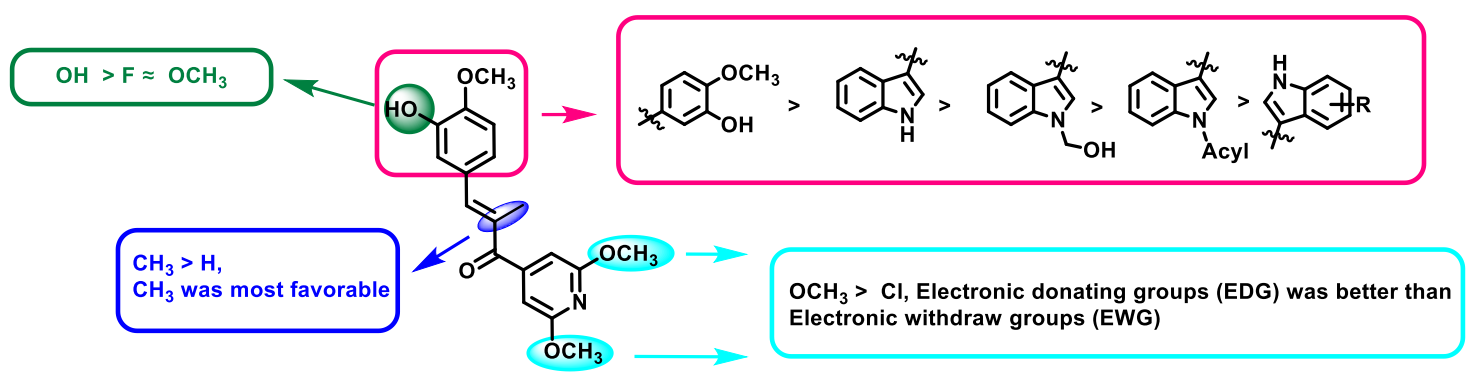

Figure 3. Summarized SARs of synthesized compounds.

\subsection{In vitro tubulin polymerization inhibitory assay}

To verify whether the target molecules interacted with microtubule systems, 16f, the most cytotoxic compounds, was selected for the experiment of effects on microtubule dynamics. Also colchicine (a typical microtubule-destabilizing agent) and taxol (microtubule-stabilizing agent) were chosen as the controls. As shown in Figure 4, the fluorescence emission of $\mathbf{1 6} \mathbf{f}$ was less than the control group and similar to the colchicine group, indicating that $\mathbf{1 6 f}$ was a microtubule-destabilizing agent. Moreover, the calculated $\mathrm{IC}_{50}$ value of $\mathbf{1 6} \mathbf{f}$ in inhibiting tubulin polymerization was $2.08 \mu \mathrm{M}$, which was better than the CA-4 $\left(\mathrm{IC}_{50}=2.17 \mu \mathrm{M}\right)$ and the parent compound 2a $\left(\mathrm{IC}_{50}=3.05 \mu \mathrm{M}\right)$ (Table 3$)$. In addition, the test of competing with [3H]-colchicine in binding to tubulin was performed, indicating that $\mathbf{1 6} \mathbf{f}$ bound to the colchicine binding site with the potency about $87.9 \%$ at $5 \mu \mathrm{M}$, (Table 3). Hence, $\mathbf{1 6 f}$ was chosen for further 
mechanism studies due to its excellent activities both in the in vitro antiproliferative assay and tubulin polymerization inhibition assay.

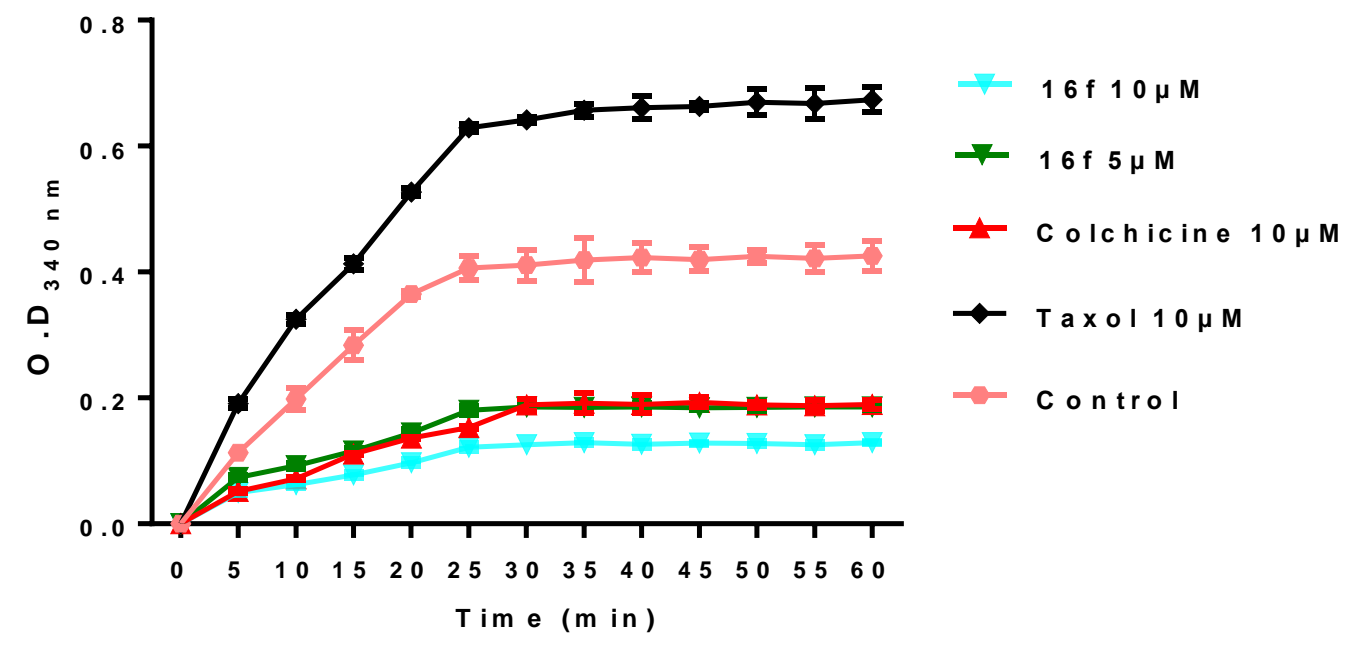

Figure 4. Effects of $\mathbf{1 6 f}$ on tubulin polymerization in vitro. Purified tubulin protein at $2 \mathrm{mg} / \mathrm{mL}$ in a reaction buffer was incubated at $37^{\circ} \mathrm{C}$ in the presence of $1 \%$ DMSO, test compounds (16f at 5 or $10 \mu \mathrm{M})$, Colchicine $(10 \mu \mathrm{M})$ or Taxol $(10 \mu \mathrm{M})$. Polymerizations were followed by an increase in fluorescence emission at $350 \mathrm{~nm}$ over a $60 \mathrm{~min}$ period at $37^{\circ} \mathrm{C}$. The experiments were performed three times.

Table 3. Inhibition of tubulin polymerization ${ }^{\mathrm{a}}$ and colchicine binding to tubulin ${ }^{\mathrm{b}}$

\begin{tabular}{cccc}
\hline & inhibition of tubulin polymerization & \multicolumn{2}{r}{$\begin{array}{r}\text { inhibition of colchicine binding } \\
(\%)\end{array}$} \\
& $\mathrm{IC}_{50}(\mu \mathrm{M})$ & $1 \mu \mathrm{M}$ & $5 \mu \mathrm{M}$ \\
$\mathbf{1 6 f}$ & $2.08 \pm 0.12$ & $75.1 \pm 1.63$ & $87.9 \pm 2.18$ \\
CA-4 & $2.17 \pm 0.14$ & $81.2 \pm 2.01$ & $91.7 \pm 4.40$ \\
$\mathbf{2 a}$ & $3.05 \pm 0.15$ & $70.2 \pm 1.71$ & $78.3 \pm 3.39$ \\
\hline
\end{tabular}

${ }^{\text {a }}$ The tubulin assembly assay measured the extent of assembly of $2 \mathrm{mg} / \mathrm{mL}$ tubulin after $60 \mathrm{~min}$ at

$37{ }^{\circ} \mathrm{C}$. Data are presented as mean from three independent experiments.

${ }^{\text {b }}$ Tubulin, $1 \mu \mathrm{M}$; [3H]-colchicine, $5 \mu \mathrm{M}$; and inhibitors, 1 or $5 \mu \mathrm{M}$.

\subsection{Anti-microtubule effects in K562 cells}

Immunofluorescent assay was performed to investigate the effects of compound 16f on microtubule networks. As shown in Figure 5, K562 cells and MAD-MB-231 
cells without drug treatment exhibited normal filamentous arrays. However, after exposure to $\mathbf{1 6 f}(10 \mathrm{nM}, 20 \mathrm{nM}, 40 \mathrm{nM}$ to K562, and $20 \mathrm{nM}, 40 \mathrm{nM}, 80 \mathrm{nM}$ to MADMB-231) for $24 \mathrm{~h}$, the microtubule networks in cytosol were disrupted; these results indicated that $\mathbf{1 6 f}$ can induce a dose-dependent collapse of the microtubule networks.

A)

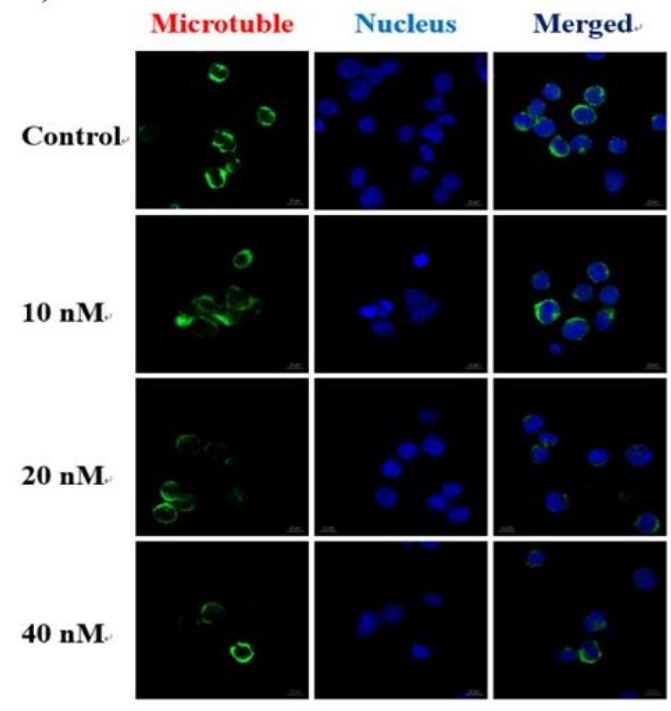

B)

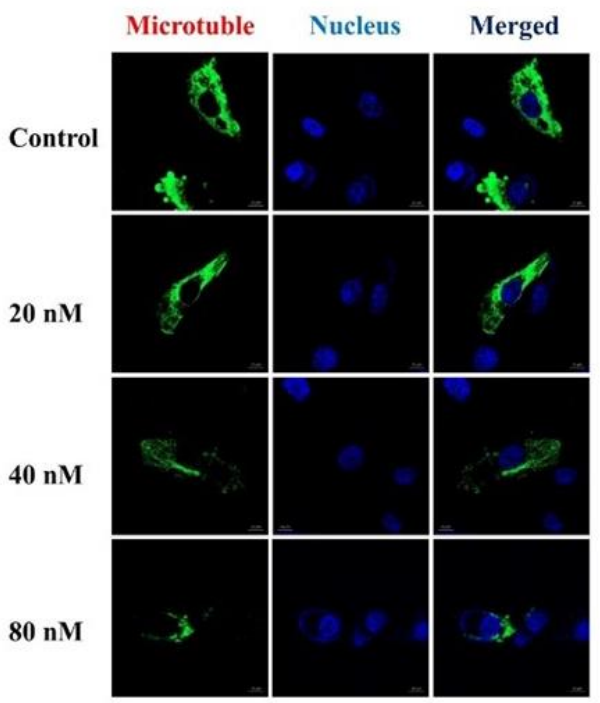

Figure 5. A) Effects of $\mathbf{1 6 f}$ on the cellular microtubule network visualized by immunofluorescence. K562 cells were treated with vehicle control 0.1\% DMSO, $\mathbf{1 6 f}(10 \mathrm{nM}), \mathbf{1 6 f}(20 \mathrm{nM})$, and $\mathbf{1 6 f}(40$ nM). B) Effects of $\mathbf{1 6 f}$ on the cellular microtubule network visualized by immunofluorescence. MAD-MB-231 cells were treated with vehicle control 0.1\% DMSO, $16 \mathbf{f}(20 \mathrm{nM}), \mathbf{1 6 f}(40 \mathrm{nM})$, and $16 f(80 \mathrm{nM})$.Then, the cells were fixed and stained with anti- $\alpha$-tubulin-FITC antibody (green), Alexa Fluor 488 dye and counterstained with DAPI (blue). The detection of the fixed and stained cells was performed with an LSM 570 laser confocal microscope (Carl Zeiss, Germany).

\subsection{Cell cycle analysis}

Since most microtubule polymerization inhibitors disrupt cell mitosis and exert cell cycle arrest effects, the effect of $\mathbf{1 6 f}$ on cell cycle progression using propidiumiodide (PI) staining in K562 cells was examined. As illustrated in Figure 6A and 6B, incubation with $16 \mathbf{f}$ blocked the cell cycle at the G2/M phase. Compared to the control cells incubated with DMSO, the incubation of K562 cells with increasing concentrations of $\mathbf{1 6 f}(15,30$, and $60 \mathrm{nM})$ increased the percentage of cells in the G2/M 
phase from $7.10 \%$ to $33.22 \%$.

A)

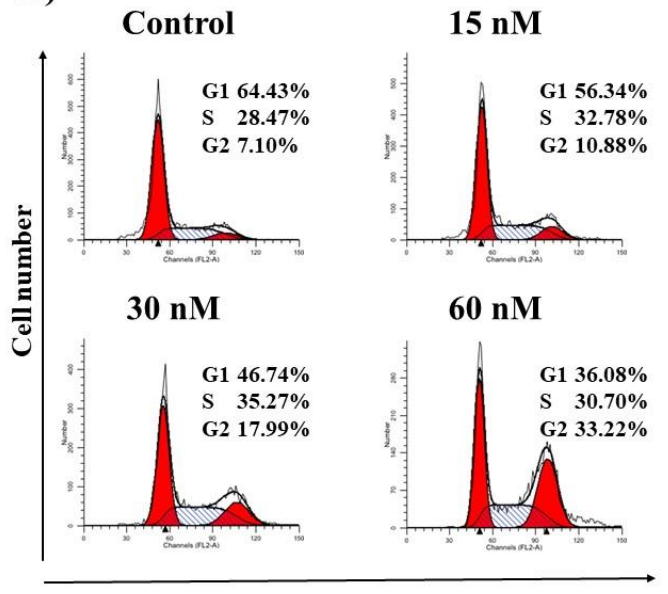

B)

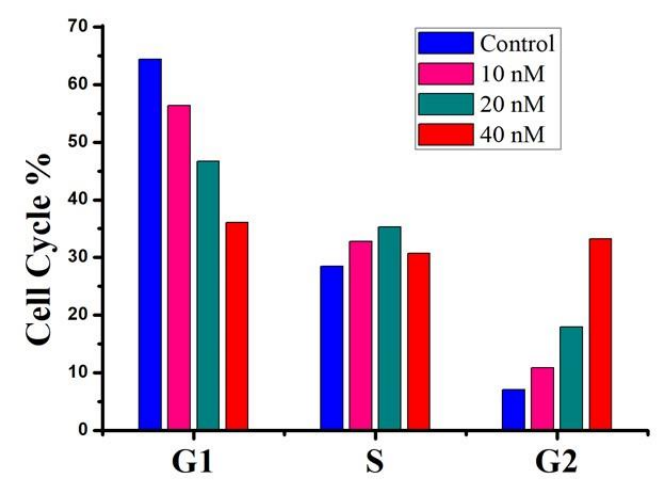

Figure 6. A) Compound 16f induced G2/M arrest in K562 cells. K562 cells were incubated with varying concentrations of $\mathbf{1 6 f}(0,15,30$, and $60 \mathrm{nM})$ for $48 \mathrm{~h}$. Cells were harvested and stained with PI and then analyzed by flow cytometry. The percentages of cells in different phases of the cell cycle were analyzed by ModFit 4.1; B) Histograms display the percentage of cell cycle distribution after treatment with $\mathbf{1 6 f}$.

\subsection{Cell apoptosis analysis}

Most microtubule polymerization inhibitors can induce cell apoptosis by upregulating the expression of pro-apoptotic proteins and down-regulating the expression of antiapoptotic proteins. Aiming to assess whether compound $\mathbf{1 6 f}$ would induce cell apoptosis, an annexin VFITC and propidium iodide (PI) assay was carried out. As shown in Figure 7A and 7B, the percentage of apoptotic cells after the $48 \mathrm{~h}$ treatment was only $3.42 \%$ in the control group, but the total numbers of early (annexin- $\mathrm{V}^{+} / \mathrm{PI}^{-}$) and late (annexin- $\mathrm{V}^{+} / \mathrm{PI}^{+}$) apoptotic cells increased to $15.79 \%, 39.01 \%$ and $56.07 \%$ after treatment with $\mathbf{1 6 f}$ at 10,20 , and $40 \mathrm{nM}$ for $48 \mathrm{~h}$, respectively. These results confirmed that compound $\mathbf{1 6 f}$ effectively induced cell apoptosis in K562 cells in a dosedependent manner. 
A)

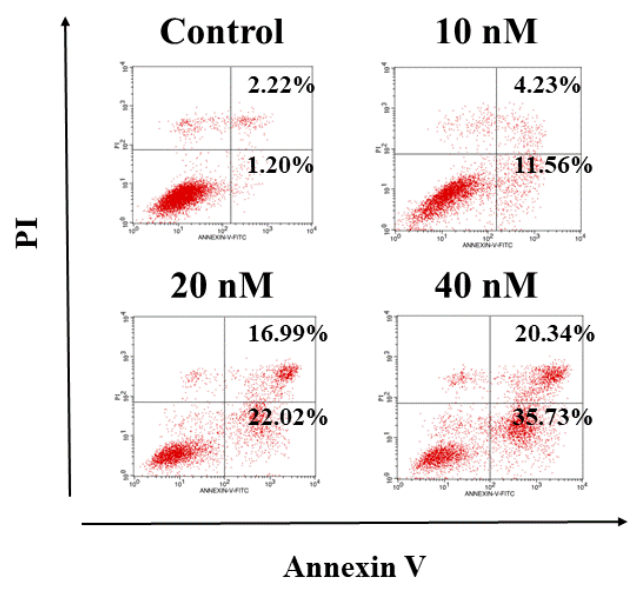

B)

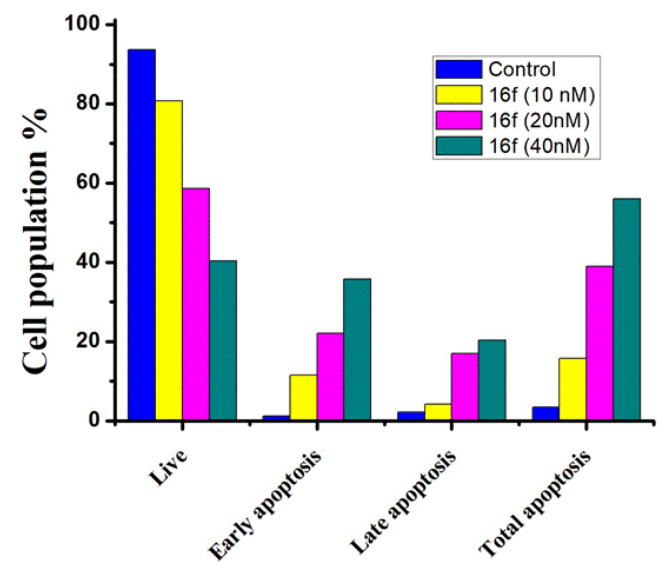

Figure 7. A) Compound 16f induced apoptosis in K562 cells. K562 cells were incubated with varying concentrations of $\mathbf{1 6 f}(0,10,20$, and $40 \mathrm{nM})$. After $48 \mathrm{~h}$ of incubation, cells were collected and stained with Annexin V/PI, followed by flow cytometric analysis. The percentages of cells in each stage of cell apoptosis were quantified by flow cytometry: (upper left quadrant) necrosis cells; (upper right quadrant) late-apoptotic cells; (bottom left quadrant) live cells; and (bottom right quadrant) early apoptotic cells. B) Histograms display the percentage of cell distribution after treatment with $\mathbf{1 6 f}$.

\subsection{Mitochondrial membrane potential analysis.}

Decreased mitochondrial membrane potential (MMP) has been implicated as an early event in apoptotic cells. Thus, the effect of compound 16f on MMP of K562 cells was determined by staining with lipophilic cationic JC-1 dye. When treated with $\mathbf{1 6}$ at concentrations of $0,10,20$ and $40 \mathrm{nM}$ for $24 \mathrm{~h}$, the number of $\mathrm{K} 562$ cells with collapsed MMP increased to $5.75 \%, 16.44 \%, 28.10 \%$ and $44.49 \%$, respectively. (Figure 8), suggesting that $\mathbf{1 6 f}$ caused mitochondrial depolarization of K562 cells in the process of apoptosis. 

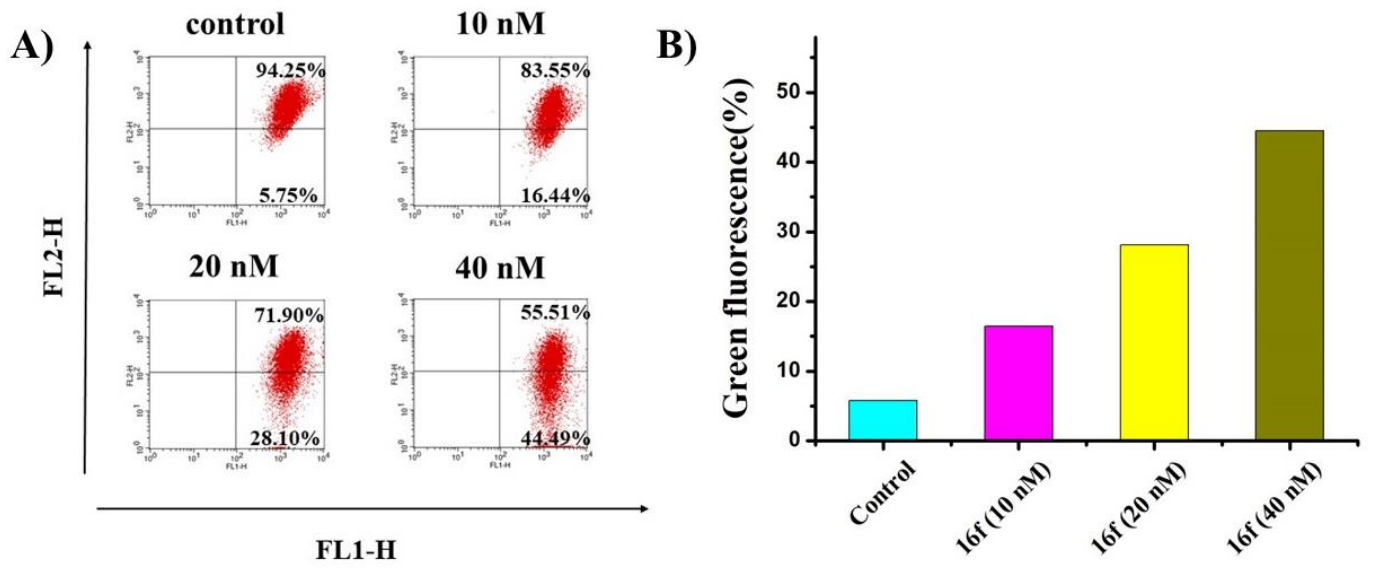

Figure 8. Effects of $\mathbf{1 6 f}$ on the mitochondrial membrane potential of K562 cells. A) Incubation with different concentrations $(0,10,20$, and $40 \mathrm{nM})$ of $\mathbf{1 6 f}$ in $\mathrm{K} 562$ cells for $24 \mathrm{~h}$ prior to staining with JC-1 dye, the number of cells with collapsed mitochondrial membrane potentials was determined by flow cytometry analysis. B) Histograms display the percentage of green fluorescence.

\subsection{In vitro evaluation of anti-vascular activity}

In view of such facts that most CBSIs possess vascular disrupting activity, we further evaluated the anti-vascular activity of compound 16f. The HUVECs culture assays were performed to assess the ability of $\mathbf{1 6 f}$ to inhibit HUVECs migration which is the key step to generate new blood vessels. As shown in Figure 9A, the untreated cells migrated to fill the area that was initially scraped after $24 \mathrm{~h}$. In contrast, $\mathbf{1 6 f}$ significantly inhibited the HUVEC migration in a dose-dependent manner.

Then we further assessed the anti-vascular activity of $\mathbf{1 6} \mathbf{f}$ in a tube formation assay. After being seeded on Matrigel, HUVECs formed the capillary-like tubules with multicentric junctions. After exposure to $\mathbf{1 6 f}$ at 10,20 , and $40 \mathrm{nM}$ for $6 \mathrm{~h}$, the capillarylike tubes were interrupted in different levels (Figure 9B). These results showed that compound $\mathbf{1 6 f}$ effectively has an effect on tubule-like disruption of HUVECs.

The antiproliferative activity of $\mathbf{1 6 f}$ against HUVECs was also determined by an MTT assay to exclude the possibility that the anti-vascular activity of $\mathbf{1 6 f}$ was due to a cytotoxic action of $\mathbf{1 6 f}$. The calculated $\mathrm{IC}_{50}$ value of $\mathbf{1 6 f}$ against HUVECs after a $24 \mathrm{~h}$ treatment was $0.126 \pm 0.007 \mu \mathrm{M}$, which is higher than the concentration of $40 \mathrm{nM}$ 
required for the obvious inhibition of cell migration and tube formation. These results indicate that $\mathbf{1 6 f}$ exhibited anti-vascular activity.

A)

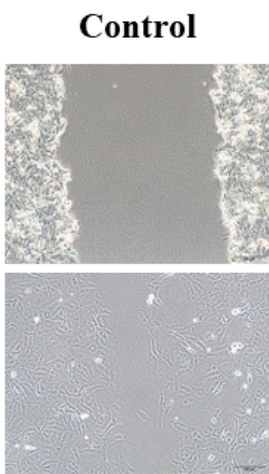

$10 \mathrm{nM}$

$20 \mathrm{nM}$

40nM

0h
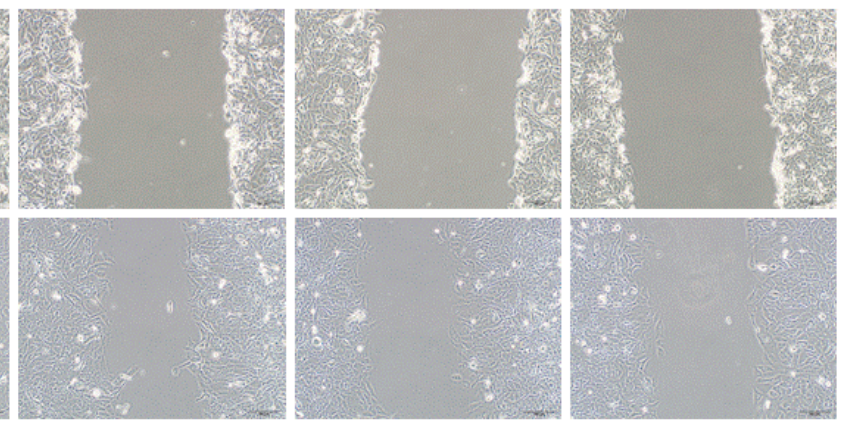

B)

Control

$10 \mathrm{nM}$

20nM

40nM
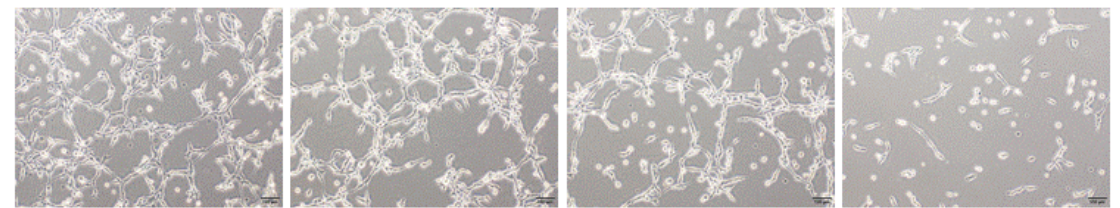

C)

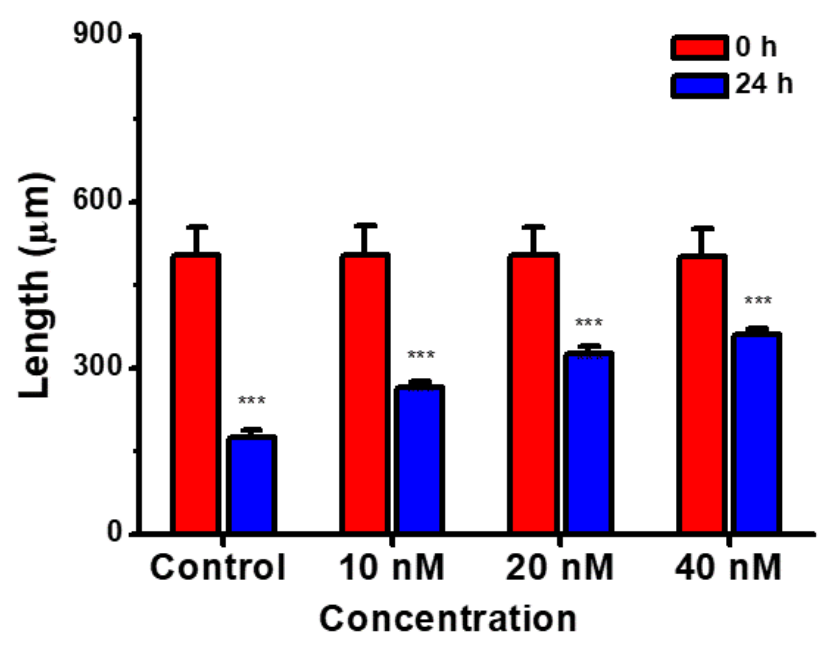

Figure 9. Effects on the HUVECs migration and tube formation. A) Scratches were created with sterile $200 \mu \mathrm{L}$ pipette and images were captured using phase contrast microscopy at $0 \mathrm{~h}$ and $24 \mathrm{~h}$ after treatments with $0,10,20$ and $40 \mathrm{nM}$ of 16f. B) Images depicting the formation of HUVEC capillary-like tubular network by treatments with $0,10,20$ and $40 \mathrm{nM}$ of $\mathbf{1 6 f}$ for $6 \mathrm{~h}$. C) Histograms display the length of the scratches at $0 \mathrm{~h}$ and $24 \mathrm{~h}$ after treatments with $0,10,20$ and $40 \mathrm{nM}$ of $\mathbf{1 6 f}$, $* * *, P<0.001$ vs control group.

\subsection{In vivo antitumor activity of $\mathbf{1 6 f}$}


To evaluate the in vivo antitumor activities of $\mathbf{1 6 f}$, liver cancer allograft mouse model was established by subcutaneous inoculation of H22 cells into the right flank of mice. The tumor size and body weights of the mice were monitored and recorded every 2 days. Paclitaxel (PTX), CA-4 and the disodium phosphate of CA-4 (CA-4P) were selected as the positive controls. As shown in Figure 10A and Figure 10B, 16f at the dose of $20 \mathrm{mg} / \mathrm{kg}$ per day significantly decreased the tumor volume. Obviously, the reduction in tumor weight reached $65.8 \%$ at dose of $20 \mathrm{mg} / \mathrm{kg}$ per day (i.v.) of $\mathbf{1 6 f}$, which was slightly less potent than PTX (72.7\% at a dose of $6 \mathrm{mg} / \mathrm{kg}$ per 2 days). Particularly, $\mathbf{1 6}$ at the dose of $20 \mathrm{mg} / \mathrm{kg}$ displayed more potent antitumor activity than CA-4 (inhibition rate: $50.9 \%$ at $20 \mathrm{mg} / \mathrm{kg}$ ) or CA-4P (inhibition rate: $62.7 \%$ at $20 \mathrm{mg} / \mathrm{kg}$ ) (Figure 10D). Moreover, 16f did not significantly affected body weight even at the doses of $20 \mathrm{mg} / \mathrm{kg}$, while treatment with PTX at a dose of $6 \mathrm{mg} / \mathrm{kg}$ per 2 days led to a significant influence on body weight (Figure 10C). Thus, compound 16f is worthy of further investigation for the treatment of cancers.

A)

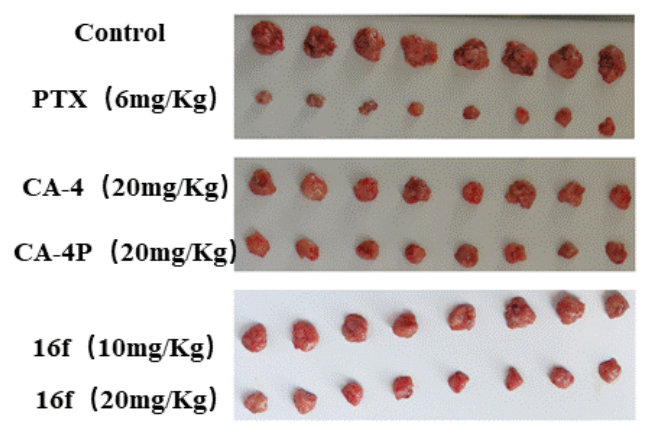

C)

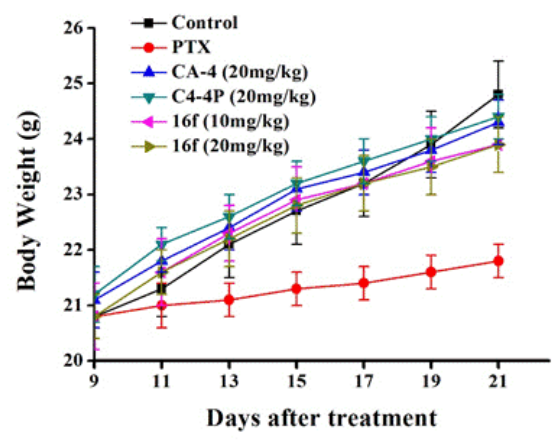

B)

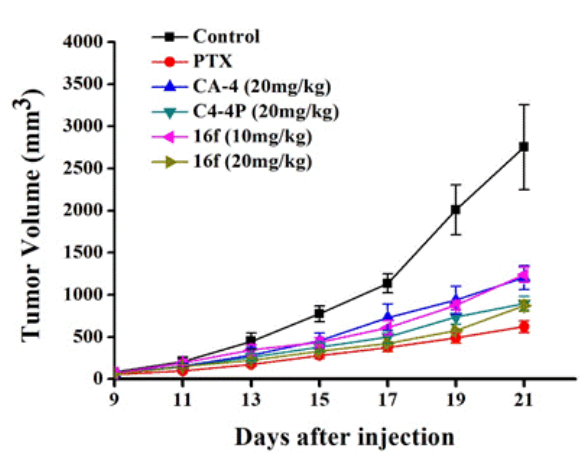

D)

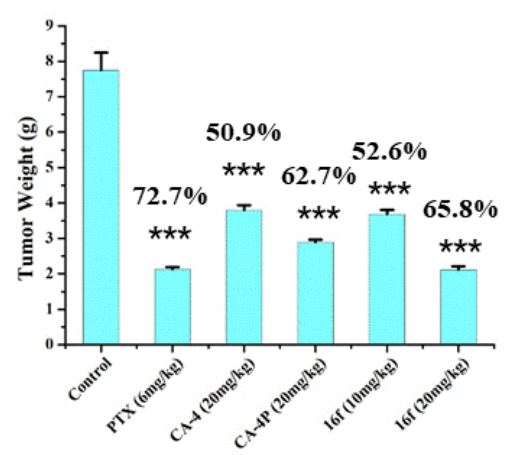

Figure 10. 16f inhibited liver cancer allograft growth in vivo. After administered with vehicle, PTX 
(6 mg/kg per 2 days, group 2), CA-4 (20 mg/kg per day), CA-4P (20 mg/kg per day), $16 \mathbf{f}(10 \mathrm{mg} / \mathrm{kg}$ per day), and $\mathbf{1 6 f}$ ( $20 \mathrm{mg} / \mathrm{kg}$ per day) for three weeks, the mice were sacrificed, and the tumors were weighed. A) The images of tumors from mice at 21 days after initiation of treatment. B) Tumor volume changes of mice during treatment. C) Body weight changes of mice during treatment. D) The weight of the excised tumors of each group. ${ }^{* *} P<0.05, * * * P<0.001 v s$ control group.

\subsection{Molecular modelling studies}

To explain the binding modes of the most active compound 16f with tubulin, we performed a docking study of $\mathbf{1 6 f}$ into the colchicine binding pocket of tubulin (PDB: 5lyj) by using the DOCK program in the Discovery Studio 3.0 software. As shown in figure 11A, 16f adopted a very similar positioning to the colchicine at the colchicine binding pocket. As displayed in figure 11B, the $N-1$ of pyridine moiety formed a critical hydrogen bond with residue Cys241 resembling that of the 4-methoxy group in compound 2a. Moreover, the hydroxy group of ring B formed two additional hydrogen bonds with Val181 and Asn258, which illustrated the vital role of the exposed hydroxyl group.

A)

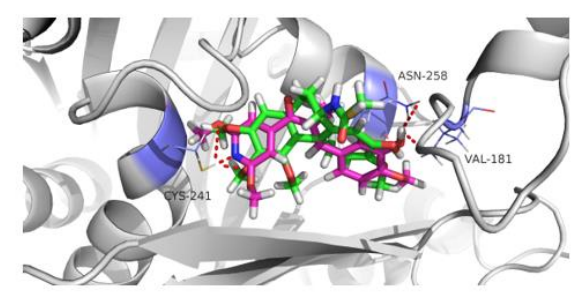

B)

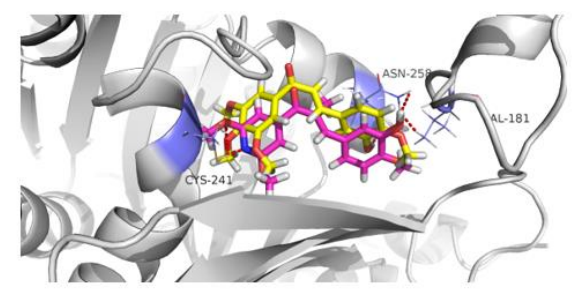

Figure 11. Proposed binding model for $\mathbf{1 6 f}$ (violet) binding with tubulin (PDB code: 5lyj), and overlapping with colchicine (green) and compound 2a (yellow).

\section{Conclusion}

In summary, we designed and synthesized a series of novel pyridine-chalcone derivatives as microtubule destabilizing agents, which may have some potential advantages over the reported chalcones. 
All compounds were evaluated for their anti-proliferative activities, and their detailed SARs were obtained. Compound 16f exhibited the most potent activities against five cancer cell lines with $\mathrm{IC}_{50}$ values ranging from 23 to $45 \mathrm{nM}$, which was 3fold more potent than parent compound 2a. Compared to chalcone derivatives without nitrogenous heterocycles, such as $\mathbf{2} \mathbf{a}$ and $\mathbf{2 b}$, the introduction of pyridine moiety, which can be further prepared as the hydrochloride salts, provides an alternative method to improve the solubility of CBSIs. On the other hand, compound $\mathbf{1 6} \mathbf{f}$ has a promising application in development for its simpler processing than that of the quinolinechalcone derivatives in our previous study [20].

Besides, by using colchicine competition inhibition assay and molecular modelling studies, representative compound $\mathbf{1 6 f}$ was verified to bind to the colchicine binding site as microtubule-destabilizing agent with the $\mathrm{IC}_{50}$ value of $2.08 \mu \mathrm{M}$. Further mechanism studies demonstrated that $\mathbf{1 6 f}$ disrupted microtubule networks, arrested cell cycle at G2/M phase, induced apoptosis and depolarized mitochondria of K562 cells in a dosedependent manner. Furthermore, the wound healing and tube formation assays also identified 16f as a novel vascular disrupting agent. The most importantly, the in vivo antitumor experiments displayed that $\mathbf{1 6 f}$ effectively suppressed the tumor volume and reduced tumor weight by $65.8 \%$ at the dose of $20 \mathrm{mg} / \mathrm{kg}$ per day (i.v.), which was more potent than control compound CA-4 (inhibition rate: $50.9 \%$ at $20 \mathrm{mg} / \mathrm{kg}$ ) or CA-4P (inhibition rate: $62.7 \%$ at $20 \mathrm{mg} / \mathrm{kg}$ ). Collectively, the present study demonstrates that pyridine-chalcone derivative $\mathbf{1 6 f}$ represents a novel class of anti-tubulin agent with potent anti-vascular and antitumor activities and deserves further investigation.

\section{EXPERIMENTAL SECTION}

\subsection{Chemistry}

\subsubsection{General}

Most chemicals and solvents were purchased from commercial sources. Further purification and drying by standard methods were employed when necessary. ${ }^{1} \mathrm{H}$ NMR and ${ }^{13} \mathrm{C}$ NMR spectra were recorded on Bruker-300 spectrometers in the indicated 
solvents (TMS as internal standard). Data are reported as follows: chemical shift in ppm (d), multiplicity ( $\mathrm{s}=$ singlet, $\mathrm{d}=$ doublet, $\mathrm{t}=$ triplet, $\mathrm{q}=$ quartet, brs = broad singlet, $\mathrm{m}$ $=$ multiplet), coupling constant $(\mathrm{Hz})$, and integration. High Resolution Mass measurement was performed on Agilent QTOF 6520 mass spectrometer with electron spray ionization (ESI) as the ion source. Flash column chromatography was carried out using commercially available silica gel (200-300 mesh) under pressure.

\subsubsection{Synthesis of intermediate 5}

To a solution of 2,6-dichloroisonicotinic acid $(10 \mathrm{~g}, 52 \mathrm{mmol})$ in $50 \mathrm{~mL}$ anhydrous THF under nitrogen atmosphere at $0{ }^{\circ} \mathrm{C}$ was added $\mathrm{C}_{2} \mathrm{H}_{5} \mathrm{MgBr}$ in diethyl ether $(2 \mathrm{M}$, $80 \mathrm{~mL}, 160 \mathrm{mmol})$. After stirring for $2 \mathrm{~h}$, the reaction was quenched by $\mathrm{NH}_{4} \mathrm{Cl}$ aqueous, and extracted with $\mathrm{CH}_{2} \mathrm{Cl}_{2}(3 \times 50 \mathrm{~mL})$. The combined organic layers were then washed with brine, dried over anhydrous $\mathrm{Na}_{2} \mathrm{SO}_{4}$, and concentrated in vacuo to provide the crude product, which was purified by column chromatography with petroleum/ethyl acetate (4:1) to give intermediate 5 as white solid (9.0 g, 85.1\%). ${ }^{1} \mathrm{H}$ NMR (300 MHz, $\left.\mathrm{CDCl}_{3}\right) \delta 7.67(\mathrm{~s}, 2 \mathrm{H}), 2.96(\mathrm{q}, J=7.1 \mathrm{~Hz}, 2 \mathrm{H}), 1.22(\mathrm{t}, J=7.1 \mathrm{~Hz}, 3 \mathrm{H}),{ }^{13} \mathrm{C}$ NMR $(75$

$\left.\mathrm{MHz}, \mathrm{CDCl}_{3}\right) \delta 197.15,151.85,147.70,120.91,32.64,7.54$; ESI-MS $m / z: 202.9$ $[\mathrm{M}+\mathrm{Na}]^{+} 225.9$.

\subsubsection{Synthesis of intermediate 6}

To a solution of $\mathbf{5}(6 \mathrm{~g}, 29.4 \mathrm{mmol})$ in anhydrous toluene was added DBU $(12.43 \mathrm{~mL}$, $88.2 \mathrm{mmol}), 2$-bromoethanol (10.42 $\mathrm{mL}, 147 \mathrm{mmol})$. The mixture was stirred at $80{ }^{\circ} \mathrm{C}$ overnight. Then the solvent was removed in vacuo, and the residue was diluted by $\mathrm{H}_{2} \mathrm{O}$, and extracted with $\mathrm{CH}_{2} \mathrm{Cl}_{2}(3 \times 20 \mathrm{~mL})$. The combined organic layers were then washed with brine, dried over anhydrous $\mathrm{Na}_{2} \mathrm{SO}_{4}$, and concentrated in vacuo to provide the crude product, which was purified by column chromatography with petroleum/ethyl acetate (40:1) to give intermediate 6 as colorless oil (6 g, 83.2\%). ${ }^{1} \mathrm{H}$ NMR $(300 \mathrm{MHz}$, $\left.\mathrm{CDCl}_{3}\right) \delta 7.33(\mathrm{~s}, 2 \mathrm{H}), 4.05(\mathrm{t}, J=6.8 \mathrm{~Hz}, 2 \mathrm{H}), 3.78(\mathrm{t}, J=6.9 \mathrm{~Hz}, 2 \mathrm{H}), 1.85(\mathrm{q}, J=7.6$ $\mathrm{Hz}, 2 \mathrm{H}), 0.89$ (t, $J=7.4 \mathrm{~Hz}, 3 \mathrm{H})$; ESI-MS m/z: $247.0[\mathrm{M}+\mathrm{Na}]^{+} 270.0$.

\subsubsection{Synthesis of intermediate $9 a$}

To a solution of $6(2.5 \mathrm{~g}, 10.1 \mathrm{mmol})$ in anhydrous $\mathrm{MeOH}$ was added sodium 
methoxide solid $(5.45 \mathrm{~g}, 101 \mathrm{mmol})$. The mixture was stirred at $60{ }^{\circ} \mathrm{C}$ in sealed tube overnight. Then the reaction was quenched by $\mathrm{H}_{2} \mathrm{O}$, the solvent was removed in vacuo, and the residue was extracted with $\mathrm{CH}_{2} \mathrm{Cl}_{2}(3 \times 20 \mathrm{~mL})$. The combined organic layers were then washed with brine, dried over anhydrous $\mathrm{Na}_{2} \mathrm{SO}_{4}$, and concentrated in vacuo to provide the crude product, which was dissolved in $\mathrm{MeOH}$, and concentrated hydrochloric acid $(10 \mathrm{~mL})$ was added. Then the mixture was stirred at room temperature for $2 \mathrm{~h}$. Then, the solution was neutralized with $2 \mathrm{M} \mathrm{NaOH}$ aqueous to $\mathrm{pH} 7$, and extracted with $\mathrm{CH}_{2} \mathrm{Cl}_{2}(3 \times 20 \mathrm{~mL})$. The combined organic layers were then washed with brine, dried over anhydrous $\mathrm{Na}_{2} \mathrm{SO}_{4}$, and concentrated in vacuo to provide the crude product, which was purified by column chromatography with petroleum/ethyl acetate (4:1) to give intermediate 9a as yellow solid (1.5 g, 79.1\%). ${ }^{1} \mathrm{H}$ NMR (300 MHz, $\left.\mathrm{CDCl}_{3}\right) \delta 7.33(\mathrm{~s}, 1 \mathrm{H}), 7.09(\mathrm{~s}, 1 \mathrm{H}), 3.98(\mathrm{~s}, 3 \mathrm{H}), 2.93(\mathrm{q}, J=7.1 \mathrm{~Hz}, 2 \mathrm{H}), 1.25-1.17$ (m, 3H); ESI-MS m/z: $199.0[\mathrm{M}+\mathrm{Na}]^{+} 222.0$.

\subsubsection{Synthesis of intermediate $9 \mathrm{~b}$}

To a solution of 6 (5 g, $20.2 \mathrm{mmol}$ ) in anhydrous $\mathrm{MeOH}$ was added sodium methoxide solid $(10.89 \mathrm{~g}, 202 \mathrm{mmol})$. The mixture was stirred at $100{ }^{\circ} \mathrm{C}$ in sealed tube overnight. Then the reaction was quenched by $\mathrm{H}_{2} \mathrm{O}$, the solvent was removed in vacuo, and the residue was extracted with $\mathrm{CH}_{2} \mathrm{Cl}_{2}(3 \times 20 \mathrm{~mL})$. The combined organic layers were then washed with brine, dried over anhydrous $\mathrm{Na}_{2} \mathrm{SO}_{4}$, and concentrated in vacuo to provide the crude product, which was dissolved in $\mathrm{MeOH}$, and concentrated hydrochloric acid $(10 \mathrm{~mL})$ was added. Then the mixture was stirred at room temperature for $2 \mathrm{~h}$. Then, the solution was neutralized with $2 \mathrm{M} \mathrm{NaOH}$ aqueous to $\mathrm{pH} 7$, and extracted with $\mathrm{CH}_{2} \mathrm{Cl}_{2}(3 \times 20 \mathrm{~mL})$. The combined organic layers were then washed with brine, dried over anhydrous $\mathrm{Na}_{2} \mathrm{SO}_{4}$, and concentrated in vacuo to provide the crude product, which was purified by column chromatography with petroleum/ethyl acetate (4:1) to give intermediate $9 \mathrm{~b}$ as yellow solid (3.2 g, 81.1\%). ${ }^{1} \mathrm{H}$ NMR (300 MHz, CDCl3) $\delta 6.75(\mathrm{~s}, 2 \mathrm{H}), 3.95(\mathrm{~s}, 6 \mathrm{H}), 2.92(\mathrm{q}, J=6.5 \mathrm{~Hz}, 2 \mathrm{H}), 1.20(\mathrm{t}, J=7.4 \mathrm{~Hz}, 3 \mathrm{H})$.

${ }^{13} \mathrm{C}$ NMR $\left(75 \mathrm{MHz}, \mathrm{CDCl}_{3}\right) \delta 200.01,164.01,148.70,99.41,53.89,32.44,7.85$; ESIMS m/z: $195.0[\mathrm{M}+\mathrm{Na}]^{+} 218.0$.

\subsubsection{Synthesis of intermediate 10}


To a solution of $\mathbf{6}(1.5 \mathrm{~g}, 4.1 \mathrm{mmo})$ in anhydrous DCM was added HOBt (1.3 g, 4.8 $\mathrm{mmol}), \mathrm{EDCI}(1.8 \mathrm{~g}, 4.8 \mathrm{mmol}), \mathrm{Et}_{3} \mathrm{~N}(0.62 \mathrm{~g}, 6.15 \mathrm{mmol})$ and $N$-methoxymethanamine $(1.2 \mathrm{~g}, 6.6 \mathrm{mmol})$. The mixture was stirred at room temperature for $2 \mathrm{~h}$. The precipitate was filtered and the filtrate was removed under vacuum. The resulting mixture was then purified by flash column chromatography with petroleum/ethyl acetate (4:1) to give intermediate 10 as white solid (1.6 g, 85.1\%). ${ }^{1} \mathrm{H}$ NMR $\left(300 \mathrm{MHz}, \mathrm{CDCl}_{3}\right) \delta 7.50$ (s, 2H), $3.58(\mathrm{~s}, 3 \mathrm{H}), 3.37$ (s, 3H); ESI-MS $m / z: 233.9[\mathrm{M}+\mathrm{Na}]^{+} 256.9$.

\subsubsection{Synthesis of intermediate 11}

To a solution of $\mathbf{1 0}(1.1 \mathrm{~g}, 4.68 \mathrm{mmol})$ in $10 \mathrm{ml}$ anhydrous THF under nitrogen atmosphere at $0{ }^{\circ} \mathrm{C}$ was added $\mathrm{CH}_{3} \mathrm{MgBr}$ in diethyl ether $(3 \mathrm{M}, 2.34 \mathrm{~mL}, 4.80 \mathrm{mmol})$. After stirring for $2 \mathrm{~h}$, the reaction was quenched by $\mathrm{NH}_{4} \mathrm{Cl}$ aqueous, and extracted with $\mathrm{CH}_{2} \mathrm{Cl}_{2}(3 \times 20 \mathrm{~mL})$. The combined organic layers were then washed with brine, dried over anhydrous $\mathrm{Na}_{2} \mathrm{SO}_{4}$, and concentrated in vacuo to provide the crude product, which was purified by column chromatography with petroleum/ethyl acetate (4:1) to give intermediate 11 as white solid $(0.820 \mathrm{~g}, 92.1 \%) .{ }^{1} \mathrm{H} \mathrm{NMR}\left(300 \mathrm{MHz}, \mathrm{CDCl}_{3}\right) \delta 7.69$ (s, 2H), 2.64 (s, 3H); ESI-MS m/z: $188.9[\mathrm{M}+\mathrm{Na}]^{+} 211.9$.

\subsubsection{Synthesis of intermediate 14}

To a solution of $\mathbf{1 1}(1.2 \mathrm{~g}, 6.32 \mathrm{mmol})$ in anhydrous toluene was added DBU (2.67 $\mathrm{mL}, 19.0 \mathrm{mmol}), 2$-bromoethanol $(2.24 \mathrm{~mL}, 31.6 \mathrm{mmol})$. The mixture was stirred at $80{ }^{\circ} \mathrm{C}$ overnight. Then the solvent was removed in vacuo, and the residue was diluted by $\mathrm{H}_{2} \mathrm{O}$, and extracted with $\mathrm{CH}_{2} \mathrm{Cl}_{2}(3 \times 20 \mathrm{~mL})$. The combined organic layers were then washed with brine, dried over anhydrous $\mathrm{Na}_{2} \mathrm{SO}_{4}$, and concentrated in vacuo to provide the crude product $\mathbf{1 2}$ as colorless oil (1.25 g, 83.1\%). To a solution of $\mathbf{1 2}$ (1.25 $\mathrm{g}, 5.05 \mathrm{mmol})$ in anhydrous $\mathrm{MeOH}$ was added sodium methoxide (2.72 g, $50.5 \mathrm{mmol})$. The mixture was stirred at $100{ }^{\circ} \mathrm{C}$ in sealed tube overnight. Then the reaction was quenched by $\mathrm{H}_{2} \mathrm{O}$, the solvent was removed in vacuo, and the residue was extracted with $\mathrm{CH}_{2} \mathrm{Cl}_{2}(3 \times 20 \mathrm{~mL})$. The combined organic layers were then washed with brine, dried over anhydrous $\mathrm{Na}_{2} \mathrm{SO}_{4}$, and concentrated in vacuo to provide the crude product, which was dissolved in $\mathrm{MeOH}$, and concentrated hydrochloric acid (10 ml) was added. Then the mixture was stirred at room temperature for $2 \mathrm{~h}$. Then, the solution was 
neutralized with $2 \mathrm{M} \mathrm{NaOH}$ aqueous to $\mathrm{pH} 7$, and extracted with $\mathrm{CH}_{2} \mathrm{Cl}_{2}(3 \times 20 \mathrm{~mL})$. The combined organic layers were then washed with brine, dried over anhydrous $\mathrm{Na}_{2} \mathrm{SO}_{4}$, and concentrated in vacuo to provide the crude product, which was purified by column chromatography with petroleum/ethyl acetate (4:1) to give intermediate 14 as white solid (0.8 g, 81.1\%). ${ }^{1} \mathrm{H}$ NMR $\left(300 \mathrm{MHz}, \mathrm{CDCl}_{3}\right) \delta 6.74(\mathrm{~s}, 2 \mathrm{H}), 3.95(\mathrm{~s}, 6 \mathrm{H})$, $2.55(\mathrm{~s}, 3 \mathrm{H}),{ }^{13} \mathrm{C} \mathrm{NMR}\left(75 \mathrm{MHz}, \mathrm{CDCl}_{3}\right) \delta 212.48,164.06,148.74,99.70,53.94,27.01$; ESI-MS $m / z: 181.0[\mathrm{M}+\mathrm{Na}]^{+} 204$.

\subsubsection{The procedure for the preparation of $15 a-f$ and $16 a-f$.}

To a stirred solution of ketone $(0.28 \mathrm{mmol})$ and aldehyde $(0.28 \mathrm{mmol})$ in anhydrous EtOH, $\mathrm{NaOH}(55.1 \mathrm{mg}, 1.38 \mathrm{mmol})$ was slowly added at room temperature. After stirring for $3 \mathrm{~h}$, the reaction mixture was concentrated and extracted with $\mathrm{CH}_{2} \mathrm{Cl}_{2}(3 \times$ $20 \mathrm{~mL}$ ). The combined organic layers were then washed with brine, dried over anhydrous $\mathrm{Na}_{2} \mathrm{SO}_{4}$, and concentrated in vacuo to provide the crude product, which was purified by column chromatography with petroleum/ethyl acetate $(4: 1)$ to give the corresponding pure compounds $15 a-f$ and $16 a-f$.

4.1.9.1 (E)-1-(2,6-dimethoxypyridin-4-yl)-3-(4-methoxyphenyl)prop-2-en-1-one (15a). Yellow solid, yield 76.2\%. ${ }^{1} \mathrm{H}$ NMR $\left(300 \mathrm{MHz}, \mathrm{CDCl}_{3}\right) \delta 7.63(\mathrm{~d}, J=15.7 \mathrm{~Hz}, 1 \mathrm{H})$, $7.45(\mathrm{~d}, J=8.6 \mathrm{~Hz}, 2 \mathrm{H}), 7.07$ (d, $J=15.7 \mathrm{~Hz}, 1 \mathrm{H}), 6.81$ (d, $J=8.6 \mathrm{~Hz}, 2 \mathrm{H}), 6.64$ (s, 2H), $3.84(\mathrm{~s}, 6 \mathrm{H}), 3.73$ (s, 3H), ${ }^{13} \mathrm{C} \mathrm{NMR}\left(75 \mathrm{MHz}, \mathrm{CDCl}_{3}\right) \delta 189.92,163.88,162.04$, 150.74, 146.20, 130.47, 127.21, 119.61, 114.50, 99.85, 55.43, 53.89; HR-MS (ESI) $\mathrm{m} / z$ : calcd for $\mathrm{C}_{17} \mathrm{H}_{18} \mathrm{NO}_{4}[\mathrm{M}+\mathrm{H}]^{+} 300.1230$ found 300.1229 .

4.1.9.2 (E)-3-(3,4-dimethoxyphenyl)-1-(2,6-dimethoxypyridin-4-yl)prop-2-en-1-one (15b). Yellow solid, yield 72.3\%. ${ }^{1} \mathrm{H}$ NMR $\left(300 \mathrm{MHz}, \mathrm{CDCl}_{3}\right) \delta 7.59(\mathrm{~d}, J=15.7 \mathrm{~Hz}$, 1H), $7.09-6.98(\mathrm{~m}, 3 \mathrm{H}), 6.75$ (d, J= $8.3 \mathrm{~Hz}, 1 \mathrm{H}), 6.63$ (s, 2H), 3.83 (s, 6H), 3.81 (s, $3 \mathrm{H}), 3.79(\mathrm{~s}, 3 \mathrm{H}),{ }^{13} \mathrm{C} \mathrm{NMR}\left(75 \mathrm{MHz}, \mathrm{CDCl}_{3}\right) \delta 189.87,163.85,151.84,150.69,149.31$, 146.50, 127.43, 123.71, 119.76, 111.11, 109.96, 99.86, 56.00, 55.96, 53.89. HR-MS (ESI) $m / z$ : calcd for $\mathrm{C}_{18} \mathrm{H}_{20} \mathrm{NO}_{5}[\mathrm{M}+\mathrm{H}]^{+} 330.1336$, found 330.1331 .

4.1.9.3 (E)-1-(2,6-dimethoxypyridin-4-yl)-3-(3,4,5-trimethoxyphenyl)prop-2-en-1-one (15c). Yellow solid, yield 83.7\%. ${ }^{1} \mathrm{H}$ NMR $\left(300 \mathrm{MHz}, \mathrm{CDCl}_{3}\right) \delta 7.57(\mathrm{~d}, J=15.7 \mathrm{~Hz}$, $1 \mathrm{H}), 7.10(\mathrm{~s}, 1 \mathrm{H}), 6.72(\mathrm{~s}, 2 \mathrm{H}), 6.65(\mathrm{~s}, 2 \mathrm{H}), 3.86(\mathrm{~s}, 6 \mathrm{H}), 3.80(\mathrm{~s}, 6 \mathrm{H}), 3.78(\mathrm{~s}, 3 \mathrm{H}),{ }^{13} \mathrm{C}$ 
NMR (75 MHz, $\left.\mathrm{CDCl}_{3}\right) \delta 189.88,163.89,153.51,150.47,146.49,140.88,129.87$, 121.20, 105.88, 99.92, 61.01, 56.25, 53.92; HR-MS (ESI) $m / z$ : calcd for $\mathrm{C}_{19} \mathrm{H}_{22} \mathrm{NO}_{6}$ $[\mathrm{M}+\mathrm{H}]^{+} 360.1442$, found 360.1440 .

4.1.9.4 (E)-1-(2,6-dimethoxypyridin-4-yl)-3-(4-(methylthio)phenyl)prop-2-en-1-one (15d). Yellow solid, yield 77.6\%. ${ }^{1} \mathrm{H}$ NMR $\left(300 \mathrm{MHz}, \mathrm{CDCl}_{3}\right) \delta 7.74(\mathrm{~d}, J=15.7 \mathrm{~Hz}$, 1H), $7.53(\mathrm{~d}, J=8.1 \mathrm{~Hz}, 2 \mathrm{H}), 7.30(\mathrm{~s}, 1 \mathrm{H}), 7.24(\mathrm{~d}, J=5.0 \mathrm{~Hz}, 2 \mathrm{H}), 6.77$ (s, 2H), 3.97 (s, 6H), $2.52(\mathrm{~s}, 3 \mathrm{H}) ;{ }^{13} \mathrm{C} \mathrm{NMR}\left(75 \mathrm{MHz}, \mathrm{CDCl}_{3}\right) \delta 205.60,163.92,156.40,150.51$, 145.81, 128.97, 125.92, 120.80, 99.86, 98.74, 53.93, 15.06. HR-MS (ESI) m/z: calcd for $\mathrm{C}_{17} \mathrm{H}_{18} \mathrm{NO}_{3} \mathrm{~S}[\mathrm{M}+\mathrm{H}]^{+}$316.1002, found 316.0998.

4.1.9.5 (E)-1-(2,6-dimethoxypyridin-4-yl)-3-(3-hydroxy-4-methoxyphenyl)prop-2-en1-one (15e). Yellow solid, yield 57.3\%. ${ }^{1} \mathrm{H} \mathrm{NMR}\left(300 \mathrm{MHz}, \mathrm{CDCl}_{3}\right) \delta 7.71(\mathrm{~d}, J=15.7$ $\mathrm{Hz}, 1 \mathrm{H}), 7.25(\mathrm{~d}, J=3.0 \mathrm{~Hz}, 1 \mathrm{H}), 7.21(\mathrm{~s}, 1 \mathrm{H}), 7.15-7.11(\mathrm{~m}, 1 \mathrm{H}), 6.88(\mathrm{~d}, J=8.3 \mathrm{~Hz}$, 1H), $6.76(\mathrm{~s}, 2 \mathrm{H}), 5.68(\mathrm{~s}, 1 \mathrm{H}), 3.97(\mathrm{~s}, 6 \mathrm{H}), 3.95$ (s, 3H), ${ }^{13} \mathrm{C} \mathrm{NMR}\left(75 \mathrm{MHz}, \mathrm{CDCl}_{3}\right)$ $\delta 163.60,163.36,161.07,153.08,152.69,149.77,136.54,106.04,105.03,99.33,98.74$, 98.03, 56.15, 53.65. HR-MS (ESI) $m / z$ : calcd for $\mathrm{C}_{17} \mathrm{H}_{18} \mathrm{NO}_{5}[\mathrm{M}+\mathrm{H}]^{+} 316.1179$, found 316.1174 .

4.1.9.6 (E)-1-(2,6-dimethoxypyridin-4-yl)-3-(3-fluoro-4-methoxyphenyl)prop-2-en-1one (15f). White solid, yield 63.7\%. ${ }^{1} \mathrm{H}$ NMR (300 MHz, $\left.\mathrm{CDCl}_{3}\right) \delta 7.56(\mathrm{~d}, J=15.7$ $\mathrm{Hz}, 1 \mathrm{H}), 7.24$ (t, $J=11.2 \mathrm{~Hz}, 2 \mathrm{H}), 7.05(\mathrm{~d}, J=15.7 \mathrm{~Hz}, 1 \mathrm{H}), 6.85(\mathrm{t}, J=8.4 \mathrm{~Hz}, 1 \mathrm{H})$, $6.63(\mathrm{~s}, 2 \mathrm{H}), 3.85(\mathrm{~s}, 6 \mathrm{H}), 3.81(\mathrm{~s}, 3 \mathrm{H}),{ }^{13} \mathrm{C} \mathrm{NMR}\left(75 \mathrm{MHz}, \mathrm{CDCl}_{3}\right) \delta$ 189.61, 163.93, 154.05, 150.36, 150.04 (d, $J=24.0 \mathrm{~Hz}), 147.85,146.01,144.95,127.69,126.31,123.80$, $120.75(\mathrm{~d}, J=228.8 \mathrm{~Hz}), 115.15,114.90$ (d, $J=18.8 \mathrm{~Hz}), 113.21,99.83,56.27,53.91$; HR-MS (ESI) $m / z$ : calcd for $\mathrm{C}_{17} \mathrm{H}_{17} \mathrm{FNO}_{4}[\mathrm{M}+\mathrm{H}]^{+} 318.1136$, found 318.1140.

4.1.9.7 (E)-1-(2,6-dimethoxypyridin-4-yl)-3-(4-methoxyphenyl)-2-methylprop-2-en-1one (16a). Yellow solid, yield 78.7\%. ${ }^{1} \mathrm{H}$ NMR (300 MHz, $\left.\mathrm{CDCl}_{3}\right) \delta 7.40(\mathrm{~d}, J=8.4$ $\mathrm{Hz}, 2 \mathrm{H}), 7.23(\mathrm{~s}, 1 \mathrm{H}), 6.96-6.89(\mathrm{~m}, 2 \mathrm{H}), 6.46(\mathrm{~s}, 2 \mathrm{H}), 3.96(\mathrm{~s}, 6 \mathrm{H}), 3.85(\mathrm{~s}, 3 \mathrm{H}), 2.23$ $(\mathrm{s}, 3 \mathrm{H}),{ }^{13} \mathrm{C}$ NMR $\left(75 \mathrm{MHz}, \mathrm{CDCl}_{3}\right) \delta 197.33,162.70,159.85,151.75,144.55,133.53$, 131.43, 127.49, 113.52, 100.07, 54.86, 53.29, 12.99. HR-MS (ESI) $\mathrm{m} / \mathrm{z}$ : calcd for $\mathrm{C}_{20} \mathrm{H}_{24} \mathrm{NO}_{6}[\mathrm{M}+\mathrm{H}]^{+} 374.1598$, found 313.1596.

4.1.9.8 (E)-3-(3,4-dimethoxyphenyl)-1-(2,6-dimethoxypyridin-4-yl)-2-methylprop-2- 
en-1-one (16b). Yellow solid, yield 86.9\%. ${ }^{1} \mathrm{H}$ NMR (300 MHz, $\left.\mathrm{CDCl}_{3}\right) \delta 7.22(\mathrm{~s}, 1 \mathrm{H})$, $7.07(\mathrm{~d}, J=8.0 \mathrm{~Hz}, 1 \mathrm{H}), 6.95-6.89(\mathrm{~m}, 2 \mathrm{H}), 6.46(\mathrm{~s}, 2 \mathrm{H}), 3.96(\mathrm{~s}, 6 \mathrm{H}), 3.93(\mathrm{~s}, 3 \mathrm{H})$, $3.90(\mathrm{~s}, 3 \mathrm{H}), 2.26(\mathrm{~s}, 3 \mathrm{H}),{ }^{13} \mathrm{C} \mathrm{NMR}\left(75 \mathrm{MHz}, \mathrm{CDCl}_{3}\right) \delta 197.26,162.72,151.73,149.49$, 148.25, 144.67, 133.82, 127.73, 123.30, 112.58, 110.41, 100.07, 55.46, 53.30, 13.07. HR-MS (ESI) $m / z$ : calcd for $\mathrm{C}_{19} \mathrm{H}_{22} \mathrm{NO}_{5}[\mathrm{M}+\mathrm{H}]^{+} 344.1492$, found 313.1493.

4.1.9.9 (E)-1-(2,6-dimethoxypyridin-4-yl)-2-methyl-3-(3,4,5-trimethoxyphenyl)prop-2en-1-one (16c). Yellow solid, yield 85.3\%. ${ }^{1} \mathrm{H}$ NMR (300 MHz, $\left.\mathrm{CDCl}_{3}\right) \delta 7.19(\mathrm{~s}, 1 \mathrm{H})$, $6.64(\mathrm{~s}, 2 \mathrm{H}), 6.47$ (s, 2H), $3.97(\mathrm{~s}, 6 \mathrm{H}), 3.89(\mathrm{~s}, 3 \mathrm{H}), 3.88(\mathrm{~s}, 6 \mathrm{H}), 2.25(\mathrm{~s}, 3 \mathrm{H}),{ }^{13} \mathrm{C} \mathrm{NMR}$ $\left(75 \mathrm{MHz}, \mathrm{CDCl}_{3}\right) \delta 197.17,162.76,152.59,151.40,144.43,138.52,134.97,130.29$, 106.93, 100.10, 60.47, 55.74, 53.31, 13.16. HR-MS (ESI) $m / z$ : calcd for $\mathrm{C}_{18} \mathrm{H}_{20} \mathrm{NO}_{4}$ $[\mathrm{M}+\mathrm{H}]^{+}$313.1387, found 313.1385.

4.1.9.10 (E)-1-(2,6-dichloropyridin-4-yl)-3-(3-hydroxy-4-methoxyphenyl)-2methylprop-2-en-1-one (16d). Yellow solid, yield 75.1\%. ${ }^{1} \mathrm{H} \mathrm{NMR}\left(300 \mathrm{MHz}, \mathrm{CDCl}_{3}\right)$ $\delta 7.13(\mathrm{~s}, 1 \mathrm{H}), 7.09(\mathrm{~s}, 1 \mathrm{H}), 7.04(\mathrm{~s}, 1 \mathrm{H}), 6.96(\mathrm{~d}, J=9.5 \mathrm{~Hz}, 1 \mathrm{H}), 6.89$ (d, J = 8.8 Hz, 1H), $6.77(\mathrm{~s}, 1 \mathrm{H}), 3.95(\mathrm{~s}, 3 \mathrm{H}), 2.24(\mathrm{~s}, 3 \mathrm{H}),{ }^{13} \mathrm{C} \mathrm{NMR}\left(75 \mathrm{MHz}, \mathrm{CDCl}_{3}\right) \delta 198.78$, $160.43,141.55,135.76,131.55,126.42,123.28,120.95,118.52,111.52,107.06,103.53$, 55.57, 15.01. HR-MS (ESI) $m / z$ : calcd for $\mathrm{C}_{16} \mathrm{H}_{14} \mathrm{Cl}_{2} \mathrm{NO}_{3}[\mathrm{M}+\mathrm{H}]^{+} 338.0345$, found 338.0352 .

4.1.9.11 (E)-1-(2-chloro-6-methoxypyridin-4-yl)-3-(3-hydroxy-4-methoxyphenyl)-2methylprop-2-en-1-one (16e). Yellow solid, yield 65.2\%. ${ }^{1} \mathrm{H}$ NMR (300 MHz, DMSOd6) $\delta 9.24(\mathrm{~s}, 1 \mathrm{H}), 7.19(\mathrm{~s}, 1 \mathrm{H}), 7.11(\mathrm{~s}, 1 \mathrm{H}), 7.06(\mathrm{~s}, 1 \mathrm{H}), 7.00(\mathrm{~s}, 2 \mathrm{H}), 6.93(\mathrm{~s}, 1 \mathrm{H})$, $3.91(\mathrm{~s}, 3 \mathrm{H}), 3.82(\mathrm{~s}, 3 \mathrm{H}), 2.15$ (s, 3H), ${ }^{13} \mathrm{C} \mathrm{NMR}\left(75 \mathrm{MHz}, \mathrm{CDCl}_{3}\right) \delta$ 197.26, 162.70, 147.23, 144.57, 136.24, 133.68, 128.15, 127.51, 126.98, 126.69, 124.14, 115.28, 110.85, 100.06, 55.51, 53.30, 12.86. HR-MS (ESI) $m / z$ : calcd for $\mathrm{C}_{17} \mathrm{H}_{17} \mathrm{ClNO}_{4}[\mathrm{M}+\mathrm{H}]^{+}$ 334.0841, found 334.0834.

4.1.9.12 (E)-1-(2,6-dimethoxypyridin-4-yl)-3-(3-hydroxy-4-methoxyphenyl)-2methylprop-2-en-1-one (16f). Yellow solid, yield 75.3\%. ${ }^{1} \mathrm{H} \mathrm{NMR}\left(300 \mathrm{MHz}, \mathrm{CDCl}_{3}\right)$ $\delta 7.18(\mathrm{~s}, 1 \mathrm{H}), 7.08(\mathrm{~d}, J=2.1 \mathrm{~Hz}, 1 \mathrm{H}), 6.97-6.92(\mathrm{~m}, 1 \mathrm{H}), 6.87(\mathrm{~d}, J=8.5 \mathrm{~Hz}, 1 \mathrm{H})$, 6.45 (s, 2H), 5.64 (s, 1H), 3.96 (s, 6H), 3.94 (s, 3H), 2.23 (s, 3H), ${ }^{13} \mathrm{C}$ NMR (75 MHz, $\left.\mathrm{CDCl}_{3}\right) \delta 162.72,151.65,146.91,144.95,144.51,128.36,127.81,127.44,122.83$, 
115.47, 109.87, 100.10, 55.49, 53.30, 13.01. HR-MS (ESI) $m / z$ : calcd for $\mathrm{C}_{18} \mathrm{H}_{20} \mathrm{NO}_{5}$ $[\mathrm{M}+\mathrm{H}]^{+} 330.1336$, found 330.1332 .

\subsubsection{The procedure for the preparation of 18a-i.}

To a stirred solution of ketone $\mathbf{9 b}(50 \mathrm{mg}, 0.34 \mathrm{mmol})$ and aldehyde $(0.34 \mathrm{mmol})$ in anhydrous EtOH, piperidine (144.9 mg, $1.72 \mathrm{mmol}$ ) was slowly added. After stirring for $10 \mathrm{~h}$ at $80{ }^{\circ} \mathrm{C}$, the reaction mixture was concentrated and extracted with $\mathrm{CH}_{2} \mathrm{Cl}_{2}(3$ $\times 20 \mathrm{~mL}$ ). The combined organic layers were then washed with brine, dried over anhydrous $\mathrm{Na}_{2} \mathrm{SO}_{4}$, and concentrated in vacuo to provide the crude product, which was purified by column chromatography with petroleum/ethyl acetate $(4: 1)$ to give the corresponding pure compounds $\mathbf{1 8 a - i}$.

4.1.10.1 (E)-1-(2,6-dimethoxypyridin-4-yl)-3-(1H-indol-3-yl)-2-methylprop-2-en-1one (18a). Yellow solid, yield 85.9\%. ${ }^{1} \mathrm{H} \mathrm{NMR}\left(300 \mathrm{MHz}, \mathrm{CDCl}_{3}\right) \delta 8.74(\mathrm{~s}, 1 \mathrm{H}), 7.70$ (s, 1H), 7.65 (d, J=2.9 Hz, 1H), 7.54 (d, $J=7.8 \mathrm{~Hz}, 1 \mathrm{H}), 7.43$ (d, $J=8.0 \mathrm{~Hz}, 1 \mathrm{H}), 7.29$ (d, $J=7.5 \mathrm{~Hz}, 1 \mathrm{H}), 7.19$ (d, $J=7.3 \mathrm{~Hz}, 1 \mathrm{H}), 6.51(\mathrm{~s}, 2 \mathrm{H}), 3.98(\mathrm{~s}, 6 \mathrm{H}), 2.28$ (s, 3H), ${ }^{13} \mathrm{C}$ NMR (75 MHz, DMSO- $\left.d_{6}\right) \delta 195.46,162.62,153.39,137.13,135.76,129.10$, $128.89,127.15,122.59,120.57,117.59,112.13,111.21,99.95,53.52,13.77$. HR-MS (ESI) $m / z$ : calcd for $\mathrm{C}_{19} \mathrm{H}_{19} \mathrm{~N}_{2} \mathrm{O}_{3}[\mathrm{M}+\mathrm{H}]^{+} 323.1390$, found 323.1388 .

4.1.10.2 (E)-1-(2,6-dimethoxypyridin-4-yl)-3-(5-methoxy-1H-indol-3-yl)-2methylprop-2-en-1-one (18b). Yellow solid, yield 77.9\%. ${ }^{1} \mathrm{H} \mathrm{NMR}\left(300 \mathrm{MHz}, \mathrm{CDCl}_{3}\right.$ ) $\delta 8.66(\mathrm{~s}, 1 \mathrm{H}), 7.63(\mathrm{~d}, J=10.0 \mathrm{~Hz}, 2 \mathrm{H}), 7.32(\mathrm{~d}, J=8.7 \mathrm{~Hz}, 1 \mathrm{H}), 6.93(\mathrm{~d}, J=10.9 \mathrm{~Hz}$, 2H), 6.52 (s, 2H), 3.97 (s, 6H), 3.84 (s, 3H), 2.26 (s, 3H), ${ }^{13} \mathrm{C} \mathrm{NMR} \mathrm{(75} \mathrm{MHz,} \mathrm{CDCl}_{3}$ ) $\delta 196.85,163.22,155.22,136.87,131.52,130.81,130.53,128.26,127.16,113.21$, 112.15, 110.40, 101.08, 100.70, 55.92, 53.78, 14.29. HR-MS (ESI) $\mathrm{m} / \mathrm{z}$ : calcd for $\mathrm{C}_{20} \mathrm{H}_{21} \mathrm{~N}_{2} \mathrm{O}_{4}[\mathrm{M}+\mathrm{H}]^{+}$353.1496, found 353.1497.

4.1.10.3 (E)-1-(2,6-dimethoxypyridin-4-yl)-3-(6-methoxy-1H-indol-3-yl)-2methylprop-2-en-1-one (18c). Yellow solid, yield 78.3\%. ${ }^{1} \mathrm{H} \mathrm{NMR}\left(300 \mathrm{MHz}, \mathrm{CDCl}_{3}\right)$ $\delta 8.62(\mathrm{~s}, 1 \mathrm{H}), 7.64(\mathrm{~s}, 1 \mathrm{H}), 7.53(\mathrm{~d}, J=2.8 \mathrm{~Hz}, 1 \mathrm{H}), 7.40(\mathrm{~d}, J=8.6 \mathrm{~Hz}, 1 \mathrm{H}), 6.89$ (d, $J=2.1 \mathrm{~Hz}, 1 \mathrm{H}), 6.85(\mathrm{dd}, J=8.7,2.2 \mathrm{~Hz}, 1 \mathrm{H}), 6.49(\mathrm{~s}, 2 \mathrm{H}), 3.97(\mathrm{~s}, 6 \mathrm{H}), 3.85(\mathrm{~s}, 3 \mathrm{H})$, $2.25(\mathrm{~s}, 3 \mathrm{H}),{ }^{13} \mathrm{C} \mathrm{NMR}\left(75 \mathrm{MHz}, \mathrm{CDCl}_{3}\right) \delta 196.50,162.71,156.89,152.44,148.19$, $136.68,130.68,125.14,121.14,118.81,112.85,110.56,100.05,94.23,55.18,53.32$, 
13.67. HR-MS (ESI) $m / z$ : calcd for $\mathrm{C}_{20} \mathrm{H}_{21} \mathrm{~N}_{2} \mathrm{O}_{4}[\mathrm{M}+\mathrm{H}]^{+} 353.1496$, found 353.1499 .

4.1.10.4 (E)-1-(2,6-dimethoxypyridin-4-yl)-3-(5-fluoro-1H-indol-3-yl)-2-methylprop2-en-1-one (18d). Yellow solid, yield 66.5\%. ${ }^{1} \mathrm{H} \mathrm{NMR}\left(300 \mathrm{MHz}, \mathrm{CDCl}_{3}\right) \delta 8.76(\mathrm{~s}$, 1H), $7.68(\mathrm{~s}, 1 \mathrm{H}), 7.56(\mathrm{~s}, 1 \mathrm{H}), 7.35(\mathrm{~d}, J=8.2 \mathrm{~Hz}, 1 \mathrm{H}), 7.17(\mathrm{~d}, J=9.2 \mathrm{~Hz}, 1 \mathrm{H}), 7.04$ $(\mathrm{d}, J=9.2 \mathrm{~Hz}, 1 \mathrm{H}), 6.49$ (s, 2H), 3.99 (s, 6H), 2.26 (s, 3H), ${ }^{13} \mathrm{C}$ NMR (75 MHz, DMSO$\left.d_{6}\right) \delta 196.03,163.11,153.58,137.14,132.90,131.22,129.64,113.88$ (d, $\left.J=186.8 \mathrm{~Hz}\right)$, 113.75, 111.94, 111.39, 111.03, 103.63, 103.31, 100.58, 53.97, 14.40. HR-MS (ESI) $m / z$ : calcd for $\mathrm{C}_{19} \mathrm{H}_{18} \mathrm{FN}_{2} \mathrm{O}_{3}[\mathrm{M}+\mathrm{H}]^{+} 341.1296$, found 341.1298.

4.1.10.5 (E)-1-(2,6-dimethoxypyridin-4-yl)-3-(6-fluoro-1H-indol-3-yl)-2-methylprop2-en-1-one (18e). Yellow solid, yield 66.5\%. ${ }^{1} \mathrm{H} \mathrm{NMR}\left(300 \mathrm{MHz}, \mathrm{CDCl}_{3}\right) \delta 8.73(\mathrm{~s}$, 1H), $7.62(\mathrm{~s}, 2 \mathrm{H}), 7.47-7.41(\mathrm{~m}, 1 \mathrm{H}), 7.11(\mathrm{~d}, J=8.9 \mathrm{~Hz}, 1 \mathrm{H}), 7.00-6.92(\mathrm{~m}, 1 \mathrm{H})$, $6.50(\mathrm{~s}, 2 \mathrm{H}), 3.98(\mathrm{~s}, 6 \mathrm{H}), 2.26(\mathrm{~s}, 3 \mathrm{H}),{ }^{13} \mathrm{C} \mathrm{NMR}\left(75 \mathrm{MHz}, \mathrm{CDCl}_{3}\right) \delta$ 197.00, 163.24, $152.69,136.41,131.81,126.82,124.02,119.67,119.54,113.30,110.08(\mathrm{~d}, J=241.5$ $\mathrm{Hz}$ ), 109.76, 100.56, 98.05, 97.70, 53.84, 14.23. HR-MS (ESI) $m / z$ : calcd for $\mathrm{C}_{19} \mathrm{H}_{18} \mathrm{FN}_{2} \mathrm{O}_{3}[\mathrm{M}+\mathrm{H}]^{+}$341.1296, found 341.1296.

4.1.10.6 (E)-3-(5-chloro-1H-indol-3-yl)-1-(2,6-dimethoxypyridin-4-yl)-2-methylprop2-en-1-one (18f). Yellow solid, yield 73.5\%. ${ }^{1} \mathrm{H} \mathrm{NMR}\left(300 \mathrm{MHz}, \mathrm{CDCl}_{3}\right) \delta 8.68(\mathrm{~s}$, 1H), $7.66(\mathrm{~s}, 1 \mathrm{H}), 7.55$ (s, 1H), 7.49 (s, 1H), 7.35 (d, J = $8.8 \mathrm{~Hz}, 2 \mathrm{H}), 6.49$ (s, 2H), 3.99 $(\mathrm{s}, 6 \mathrm{H}), 2.26(\mathrm{~s}, 3 \mathrm{H}),{ }^{13} \mathrm{C}$ NMR $\left(75 \mathrm{MHz}, \mathrm{DMSO}-d_{6}\right) \delta 196.10,163.10,153.50,136.78$, $134.79,130.95,130.13,128.83,125.63,123.06,117.75,114.21,111.51,100.64,54.00$, 14.48. HR-MS (ESI) $m / z$ : calcd for $\mathrm{C}_{19} \mathrm{H}_{18} \mathrm{ClN}_{2} \mathrm{O}_{3}[\mathrm{M}+\mathrm{H}]^{+} 357.1000$, found 357.1001. 4.1.10.7 (E)-3-(6-chloro-1H-indol-3-yl)-1-(2,6-dimethoxypyridin-4-yl)-2-methylprop2-en-1-one (18g). Yellow solid, yield 53.7\%. ${ }^{1} \mathrm{H}$ NMR (300 MHz, $\left.\mathrm{CDCl}_{3}\right) \delta 8.75(\mathrm{~s}$, 1H), $7.64-7.58(\mathrm{~m}, 2 \mathrm{H}), 7.42(\mathrm{~s}, 1 \mathrm{H}), 7.16(\mathrm{dd}, J=8.4,1.9 \mathrm{~Hz}, 1 \mathrm{H}), 6.74(\mathrm{~s}, 1 \mathrm{H}), 6.50$ (s, 2H), 3.98 (s, 6H), $2.26(\mathrm{~s}, 3 \mathrm{H}),{ }^{13} \mathrm{C} \mathrm{NMR}\left(75 \mathrm{MHz}, \mathrm{CDCl}_{3}\right) \delta 200.37,163.25,152.62$, $136.18,135.85,131.91,129.38,127.01,126.00,121.85,119.63,113.33,111.43,100.56$, 53.84, 14.27. HR-MS (ESI) $m / z$ : calcd for $\mathrm{C}_{19} \mathrm{H}_{18} \mathrm{ClN}_{2} \mathrm{O}_{3}[\mathrm{M}+\mathrm{H}]^{+} 357.1000$, found 357.1002 .

4.1.10.8 (E)-1-(2,6-dimethoxypyridin-4-yl)-3-(1H-indol-5-yl)-2-methylprop-2-en-1one (18h). Yellow solid, yield 86.1\%. ${ }^{1} \mathrm{H}$ NMR (300 MHz, $\left.\mathrm{CDCl}_{3}\right) \delta 8.37(\mathrm{~s}, 1 \mathrm{H}), 7.73$ 
(s, 1H), $7.43(\mathrm{~d}, J=6.5 \mathrm{~Hz}, 1 \mathrm{H}), 7.27(\mathrm{~d}, J=4.7 \mathrm{~Hz}, 3 \mathrm{H}), 6.57(\mathrm{~s}, 2 \mathrm{H}), 6.43(\mathrm{~s}, 1 \mathrm{H})$, $3.97(\mathrm{~s}, 6 \mathrm{H}), 2.25(\mathrm{~s}, 3 \mathrm{H}),{ }^{13} \mathrm{C} \mathrm{NMR}\left(75 \mathrm{MHz}, \mathrm{CDCl}_{3}\right) \delta 197.54,162.79,151.63,142.75$, $135.59,135.24,127.13,126.95,124.45,121.29,120.41,111.64,100.77,100.25,53.34$, 13.52. HR-MS (ESI) $m / z$ : calcd for $\mathrm{C}_{19} \mathrm{H}_{19} \mathrm{~N}_{2} \mathrm{O}_{3}[\mathrm{M}+\mathrm{H}]^{+} 323.1390$, found 323.1395.

4.1.10.9 (E)-1-(2,6-dimethoxypyridin-4-yl)-3-(1H-indol-6-yl)-2-methylprop-2-en-1one (18i). Yellow solid, yield 56.3\%. ${ }^{1} \mathrm{H}$ NMR $\left(300 \mathrm{MHz}, \mathrm{CDCl}_{3}\right) \delta 8.48(\mathrm{~s}, 1 \mathrm{H}), 7.77$ (s, 1H), $7.46(\mathrm{~s}, 1 \mathrm{H}), 7.39$ (d, $J=8.5 \mathrm{~Hz}, 1 \mathrm{H}), 7.29$ (d, $J=1.7 \mathrm{~Hz}, 1 \mathrm{H}), 7.23(\mathrm{~s}, 1 \mathrm{H})$, $6.58(\mathrm{~s}, 1 \mathrm{H}), 6.50(\mathrm{~s}, 2 \mathrm{H}), 3.96(\mathrm{~s}, 6 \mathrm{H}), 2.32(\mathrm{~s}, 3 \mathrm{H}),{ }^{13} \mathrm{C} \mathrm{NMR}\left(75 \mathrm{MHz}, \mathrm{CDCl}_{3}\right) \delta$ $198.18,163.23,152.64,147.59,136.14,133.51,128.02,127.27,125.37,124.62$, $123.51,111.15,103.38,100.61,53.78$, 13.59. HR-MS (ESI) $\mathrm{m} / z$ : calcd for $\mathrm{C}_{19} \mathrm{H}_{19} \mathrm{~N}_{2} \mathrm{O}_{3}[\mathrm{M}+\mathrm{H}]^{+}$323.1390, found 323.1393.

4.1.11 (E)-1-(2,6-dimethoxypyridin-4-yl)-2-methyl-3-(1-methyl-1H-indol-3-yl)prop-2en-1-one (19a). To a solution of $\mathbf{1 8 a}(90 \mathrm{mg}, 0.28 \mathrm{mmol})$ in anhydrous DMF was added $\mathrm{NaH}(10 \mathrm{mg}, 0.42 \mathrm{mmol}), \mathrm{MeI}(52 \mathrm{mg}, 0.36 \mathrm{mmol})$. After stirring at room temperature for $2 \mathrm{~h}$, the mixture was diluted with water and extracted with ethyl acetate $(3 \times 20 \mathrm{~mL})$. The combined organic layers were then washed with brine, dried over anhydrous $\mathrm{Na}_{2} \mathrm{SO}_{4}$, and concentrated in vacuo to provide the crude product, which was purified by column chromatography with petroleum/ethyl acetate (4:1) to give the 19a as yellow solid (70 mg, $78.02 \%) .{ }^{1} \mathrm{H}$ NMR (300 MHz, $\left.\mathrm{CDCl}_{3}\right) \delta 7.69$ (s, 1H), $7.52(\mathrm{~s}, 2 \mathrm{H}), 7.34$ $(\mathrm{d}, J=12.3 \mathrm{~Hz}, 2 \mathrm{H}), 7.22(\mathrm{~d}, J=7.4 \mathrm{~Hz}, 1 \mathrm{H}), 6.53-6.45(\mathrm{~m}, 2 \mathrm{H}), 3.98(\mathrm{~s}, 6 \mathrm{H}), 3.90$ (s, 3H), 2.27 (s, 3H), ${ }^{13} \mathrm{C}$ NMR (75 MHz, $\left.\mathrm{CDCl}_{3}\right) \delta 196.82,163.19,153.14,137.08$, 136.60, 131.33, 130.09, 128.26, 123.15, 120.97, 118.66, 111.90, 109.72, 100.56, 53.82, 33.50, 14.24. HR-MS (ESI) $m / z$ : calcd for $\mathrm{C}_{20} \mathrm{H}_{21} \mathrm{~N}_{2} \mathrm{O}_{3}[\mathrm{M}+\mathrm{H}]^{+}$337.1547, found 337.1544 .

\subsubsection{2 (E)-1-(2,6-dimethoxypyridin-4-yl)-3-(1-ethyl-1H-indol-3-yl)-2-methylprop-2-}

en-1-one (19b). To a solution of $\mathbf{1 8 a}(90 \mathrm{mg}, 0.28 \mathrm{mmol})$ in anhydrous DMF was added $\mathrm{NaH}(10 \mathrm{mg}, 0.42 \mathrm{mmol})$, iodoethane $(56.6 \mathrm{mg}, 0.36 \mathrm{mmol})$. After stirring at room temperature for $2 \mathrm{~h}$, the mixture was diluted with water and extracted with ethyl acetate $(3 \times 20 \mathrm{~mL})$. The combined organic layers were then washed with brine, dried over anhydrous $\mathrm{Na}_{2} \mathrm{SO}_{4}$, and concentrated in vacuo to provide the crude product, which was 
purified by column chromatography with petroleum/ethyl acetate (4:1) to give the $\mathbf{1 9 b}$ as yellow solid (60 mg, 72.3.2\%). ${ }^{1} \mathrm{H}$ NMR $\left(300 \mathrm{MHz}, \mathrm{CDCl}_{3}\right) \delta 7.70(\mathrm{~s}, 1 \mathrm{H}), 7.57$ (s, $1 \mathrm{H}), 7.53(\mathrm{~d}, J=8.0 \mathrm{~Hz}, 1 \mathrm{H}), 7.37(\mathrm{~s}, 1 \mathrm{H}), 7.31(\mathrm{~d}, J=7.3 \mathrm{~Hz}, 1 \mathrm{H}), 7.18(\mathrm{~d}, J=7.4 \mathrm{~Hz}$, $1 \mathrm{H}), 6.49(\mathrm{~s}, 2 \mathrm{H}), 4.27(\mathrm{~d}, J=7.3 \mathrm{~Hz}, 2 \mathrm{H}), 3.97(\mathrm{~s}, 6 \mathrm{H}), 2.27(\mathrm{~s}, 3 \mathrm{H}), 1.54(\mathrm{~s}, 3 \mathrm{H}),{ }^{13} \mathrm{C}$ NMR (75 MHz, $\left.\mathrm{CDCl}_{3}\right) \delta 196.85,163.19,153.17,137.19,135.63,130.03,129.67$, 128.47, 123.04, 120.93, 118.80, 112.02, 109.81, 100.55, 53.82, 41.77, 15.34, 14.26. HR-MS (ESI) $m / z$ : calcd for $\mathrm{C}_{21} \mathrm{H}_{23} \mathrm{~N}_{2} \mathrm{O}_{3}[\mathrm{M}+\mathrm{H}]^{+} 351.1703$, found 351.1699.

4.1.13 (E)-1-(2,6-dimethoxypyridin-4-yl)-3-(1-(hydroxymethyl)-1H-indol-3-yl)-2methylprop-2-en-1-one (19c). To a solution of 18a (100 $\mathrm{mg}, 0.31 \mathrm{mmol})$ in anhydrous EtOH was added $\mathrm{HCHO}(37 \%$ in water, $1 \mathrm{~mL}), \mathrm{NaOH}(6 \mathrm{~N}, 2 \mathrm{~mL})$. After stirring at $80{ }^{\circ} \mathrm{C}$ for $2 \mathrm{~h}$, the reaction mixture was concentrated and extracted with $\mathrm{CH}_{2} \mathrm{Cl}_{2}(3 \times 20$ $\mathrm{mL})$. The combined organic layers were then washed with brine, dried over anhydrous $\mathrm{Na}_{2} \mathrm{SO}_{4}$, and concentrated in vacuo to provide the crude product, which was purified by column chromatography with petroleum/ethyl acetate (4:1) to give the 19c as yellow solid (60 mg, $55.04 \%)$. ${ }^{1} \mathrm{H}$ NMR (300 MHz, $\left.\mathrm{CDCl}_{3}\right) \delta 7.62(\mathrm{~d}, J=4.6 \mathrm{~Hz}, 2 \mathrm{H}), 7.50$ $(\mathrm{d}, J=8.0 \mathrm{~Hz}, 2 \mathrm{H}), 7.31-7.18(\mathrm{~m}, 2 \mathrm{H}), 6.43(\mathrm{~s}, 2 \mathrm{H}), 5.69(\mathrm{~s}, 2 \mathrm{H}), 3.95(\mathrm{~s}, 6 \mathrm{H}), 2.21$ $(\mathrm{s}, 3 \mathrm{H}),{ }^{13} \mathrm{C} \mathrm{NMR}\left(75 \mathrm{MHz}, \mathrm{CDCl}_{3}\right) \delta 197.24,163.20,152.62,136.95,135.47,131.20$, 129.64, 128.77, 123.64, 121.61, 118.85, 113.06, 110.12, 100.53, 70.40, 53.83, 14.28. HR-MS (ESI) $m / z$ : calcd for $\mathrm{C}_{20} \mathrm{H}_{21} \mathrm{~N}_{2} \mathrm{O}_{4}[\mathrm{M}+\mathrm{H}]^{+} 353.1496$, found 353.1492.

4.1.14 (E)-3-(1-acetyl-1H-indol-3-yl)-1-(2,6-dimethoxypyridin-4-yl)-2-methylprop-2en-1-one (19d).

To a solution of $\mathbf{1 8 a}$ (100 mg, $0.31 \mathrm{mmol})$ in anhydrous DCM was added $\mathrm{NaOH}$ (31 $\mathrm{mg}, 0.78 \mathrm{mmol})$, acetylchloride $(36.5 \mathrm{mg}, 0.47 \mathrm{mmol})$. After stirring at room temperature for $2 \mathrm{~h}$, the mixture was quenched with water and extracted with ethyl acetate $(3 \times 20 \mathrm{~mL})$. The combined organic layers were then washed with brine, dried over anhydrous $\mathrm{Na}_{2} \mathrm{SO}_{4}$, and concentrated in vacuo to provide the crude product, which was purified by column chromatography with petroleum/ethyl acetate (4:1) to give the 19d as yellow solid (80 mg, 70.80\%). ${ }^{1} \mathrm{H}$ NMR (300 MHz, $\left.\mathrm{CDCl}_{3}\right) \delta 8.43(\mathrm{~d}, J=8.2$ $\mathrm{Hz}, 1 \mathrm{H}), 7.73$ (s, 1H), $7.50-7.39$ (m, 3H), 7.34 (d, J= $7.6 \mathrm{~Hz}, 1 \mathrm{H}), 6.52$ (s, 2H), 3.98 (s, 6H), 2.74 (s, 3H), 2.31 (s, 3H), $\left.{ }^{13} \mathrm{C} \mathrm{NMR} \mathrm{(75} \mathrm{MHz,} \mathrm{CDCl}_{3}\right) \delta 196.80,168.48,163.34$, 
$151.68,135.82,133.87,129.72,126.22,125.72,124.21,118.72,117.84,116.61,100.64$, 53.86, 24.14, 14.74. HR-MS (ESI) $m / z$ : calcd for $\mathrm{C}_{21} \mathrm{H}_{21} \mathrm{~N}_{2} \mathrm{O}_{4}[\mathrm{M}+\mathrm{H}]^{+} 365.1496$, found 365.1495 .

4.1.15 (E)-1-(2,6-dimethoxypyridin-4-yl)-3-(1-(furan-2-carbonyl)-1H-indol-3-yl)-2methylprop-2-en-1-one (19e).

To a solution of $\mathbf{1 8 a}(100 \mathrm{mg}, 0.31 \mathrm{mmol})$ in anhydrous DCM was added $\mathrm{NaOH}(31$ $\mathrm{mg}, 0.78 \mathrm{mmol}), 2$-furoyl chloride $(61.3 \mathrm{mg}, 0.47 \mathrm{mmol})$. After stirring at room temperature for $2 \mathrm{~h}$, the mixture was quenched with water and extracted with ethyl acetate $(3 \times 20 \mathrm{~mL})$. The combined organic layers were then washed with brine, dried over anhydrous $\mathrm{Na}_{2} \mathrm{SO}_{4}$, and concentrated in vacuo to provide the crude product, which was purified by column chromatography with petroleum/ethyl acetate (4:1) to give the 19e as yellow solid (92 mg, $71.32 \%)$. ${ }^{1} \mathrm{H} \mathrm{NMR}\left(300 \mathrm{MHz}, \mathrm{CDCl}_{3}\right) \delta 8.47$ (d, $J=8.2$ $\mathrm{Hz}, 1 \mathrm{H}), 8.39(\mathrm{~s}, 1 \mathrm{H}), 7.77(\mathrm{~s}, 1 \mathrm{H}), 7.52(\mathrm{~d}, J=5.1 \mathrm{~Hz}, 2 \mathrm{H}), 7.42(\mathrm{~d}, J=7.8 \mathrm{~Hz}, 1 \mathrm{H})$, $7.36(\mathrm{~d}, J=7.4 \mathrm{~Hz}, 1 \mathrm{H}), 7.26(\mathrm{~s}, 1 \mathrm{H}), 6.70(\mathrm{~s}, 1 \mathrm{H}), 6.53(\mathrm{~s}, 2 \mathrm{H}), 3.99$ (s, 6H), 2.32 (s, $3 \mathrm{H}),{ }^{13} \mathrm{C} \mathrm{NMR}\left(75 \mathrm{MHz}, \mathrm{CDCl}_{3}\right) \delta 211.32,196.82,163.35,153.37,151.78,146.78$, $136.09,135.71,134.11,129.54,127.20,125.99,124.54,121.43,118.66,117.97,116.68$, 112.74, 100.66, 53.85, 14.62. HR-MS (ESI) $m / z$ : calcd for $\mathrm{C}_{24} \mathrm{H}_{21} \mathrm{~N}_{2} \mathrm{O}_{5}[\mathrm{M}+\mathrm{H}]^{+}$ 417.1445, found 417.1447.

4.1.16 (E)-3-(1-benzoyl-1H-indol-3-yl)-1-(2,6-dimethoxypyridin-4-yl)-2-methylprop2-en-1-one (19f).

To a solution of 18a (100 mg, $0.31 \mathrm{mmol})$ in anhydrous DCM was added $\mathrm{NaOH}$ (31 $\mathrm{mg}, 0.78 \mathrm{mmol})$, benzoyl chloride $(66.1 \mathrm{mg}, 0.47 \mathrm{mmol})$. After stirring at room temperature for $2 \mathrm{~h}$, the mixture was quenched with water and extracted with ethyl acetate $(3 \times 20 \mathrm{~mL})$. The combined organic layers were then washed with brine, dried over anhydrous $\mathrm{Na}_{2} \mathrm{SO}_{4}$, and concentrated in vacuo to provide the crude product, which was purified by column chromatography with petroleum/ethyl acetate (4:1) to give the 19f as yellow solid (100 mg, $75.76 \%) .{ }^{1} \mathrm{H}$ NMR $\left(300 \mathrm{MHz}, \mathrm{CDCl}_{3}\right) \delta 8.34(\mathrm{~d}, J=8.2$ $\mathrm{Hz}, 1 \mathrm{H}), 7.83-7.77(\mathrm{~m}, 2 \mathrm{H}), 7.62(\mathrm{dq}, J=14.8,7.4 \mathrm{~Hz}, 4 \mathrm{H}), 7.52-7.36(\mathrm{~m}, 4 \mathrm{H}), 6.50$ (s, 2H), 3.98 (s, 6H), 2.16 (s, 3H), ${ }^{13} \mathrm{C} \mathrm{NMR}\left(75 \mathrm{MHz}, \mathrm{CDCl}_{3}\right) \delta$ 196.76, 168.49, 163.33, $151.73,135.75,133.94,133.86,132.62,129.98,129.32,128.86,128.17,125.95$, 
124.43, 118.80, 117.24, 116.39, 100.63, 53.85, 14.54. HR-MS (ESI) $m / z$ : calcd for $\mathrm{C}_{26} \mathrm{H}_{23} \mathrm{~N}_{2} \mathrm{O}_{4}[\mathrm{M}+\mathrm{H}]^{+}$427.1652, found 427.1653.

4.1.17 (E)-1-(2,6-dimethoxypyridin-4-yl)-2-methyl-3-(1-methyl-1H-indol-5-yl)prop-2en-1-one (19g).

To a solution of $\mathbf{1 8 h}$ (90 mg, $0.28 \mathrm{mmol})$ in anhydrous DMF was added $\mathrm{NaH}(10 \mathrm{mg}$, $0.42 \mathrm{mmol}), \mathrm{MeI}(52 \mathrm{mg}, 0.36 \mathrm{mmol})$. After stirring at room temperature for $2 \mathrm{~h}$, the mixture was diluted with water and extracted with ethyl acetate $(3 \times 20 \mathrm{~mL})$. The combined organic layers were then washed with brine, dried over anhydrous $\mathrm{Na}_{2} \mathrm{SO}_{4}$, and concentrated in vacuo to provide the crude product, which was purified by column chromatography with petroleum/ethyl acetate (4:1) to give the $\mathbf{1 9 g}$ as yellow solid (75 mg, $83.59 \%) .{ }^{1} \mathrm{H}$ NMR (300 MHz, $\left.\mathrm{CDCl}_{3}\right) \delta 7.77$ (s, 1H), 7.46 (s, 1H), 7.33 (s, 2H), $7.10(\mathrm{~d}, J=3.1 \mathrm{~Hz}, 1 \mathrm{H}), 6.53(\mathrm{~d}, J=3.2 \mathrm{~Hz}, 1 \mathrm{H}), 6.49(\mathrm{~s}, 2 \mathrm{H}), 3.96(\mathrm{~s}, 6 \mathrm{H}), 3.82(\mathrm{~s}$, 3H), 2.32 (s, 3H), ${ }^{13} \mathrm{C} \mathrm{NMR}\left(75 \mathrm{MHz}, \mathrm{CDCl}_{3}\right) \delta 192.51,163.19,137.20,130.75,129.70$, $128.53,126.42,123.03,121.78,120.93,118.78,109.82,103.22,100.55,53.82,41.76$, 14.26. HR-MS (ESI) $m / z$ : calcd for $\mathrm{C}_{20} \mathrm{H}_{21} \mathrm{~N}_{2} \mathrm{O}_{3}[\mathrm{M}+\mathrm{H}]^{+} 337.1547$, found 337.1544.

\subsection{Pharmacology}

\subsubsection{In vitro antiproliferative assay}

Cells were purchased from Nanjing KeyGen Biotech Co. Ltd. (Nanjing, China). The cytotoxicity of the test compounds was determined using the MTT assay. Briefly, the cell lines were incubated at $37{ }^{\circ} \mathrm{C}$ in a humidified $5 \% \mathrm{CO}_{2}$ incubator for $24 \mathrm{~h}$ in 96microwell plates. After medium removal, $100 \mathrm{~mL}$ of culture medium with $0.1 \%$ DMSO containing the test compounds at different concentrations was added to each well and incubated at $37{ }^{\circ} \mathrm{C}$ for another $72 \mathrm{~h}$. The MTT (5 mg/mL in PBS) was added and incubated for another $4 \mathrm{~h}$, the optical density was detected with a microplate reader at $490 \mathrm{~nm}$. The $\mathrm{IC}_{50}$ values were calculated according to the dose-dependent curves. All the experiments were repeated in at least three independent experiments.

\subsubsection{In vitro tubulin polymerization inhibitory assay}

An amount of $2 \mathrm{mg} / \mathrm{mL}$ tubulin (Cytoskeleton) was resuspended in PEM buffer containing $80 \mathrm{mM}$ piperazine-N,N'-bis(2-ethanesulfonic acid) sequisodium salt PIPES 
(pH 6.9), $0.5 \mathrm{mM}$ EGTA, $2 \mathrm{mM} \mathrm{MgCl}_{2}$, and $15 \%$ glycerol. Then the mixture was preincubated with tested compounds or vehicle DMSO on ice. PEG containing GTP was added to the final concentration of $3 \mathrm{mg} / \mathrm{mL}$ before detecting the tubulin polymerization reaction. After $30 \mathrm{~min}$, the absorbance was detected by a spectrophotometer at $340 \mathrm{~nm}$ at $37^{\circ} \mathrm{C}$ every $2 \mathrm{~min}$ for $60 \mathrm{~min}$. The area under the curve was used to determine the concentration that inhibited tubulin polymerization by $50 \%$ ( $\left.\mathrm{IC}_{50}\right)$, which was calculated with GraphPad Prism Software version 5.02.

\subsubsection{Competitive Inhibition Assays.}

The competitive binding activity of tested compounds was evaluated using a radiolabeled $[3 \mathrm{H}]$ colchicine competition scintillation proximity (SPA) assay. In brief, $0.08 \mu \mathrm{M}[3 \mathrm{H}]$ colchicine was mixed with 16f $(1 \mu \mathrm{M}, 5 \mu \mathrm{M})$ or CA-4 $(1 \mu \mathrm{M}, 5 \mu \mathrm{M})$ and biotinylated porcine tubulin $(0.5 \mu \mathrm{g})$ in a buffer of $100 \mu \mathrm{L}$ containing $80 \mathrm{mM}$ PIPES (pH 6.8), $1 \mathrm{mM}$ EGTA, $10 \%$ glycerol, $1 \mathrm{mM} \mathrm{MgCl}$, and $1 \mathrm{mM} \mathrm{GTP}$ for $2 \mathrm{~h}$ at $37^{\circ} \mathrm{C}$. Then streptavidin-labeled SPA beads $(80 \mu \mathrm{g})$ were added to each mixture. The radioactive counts were measured directly with a scintillation counter.

\subsubsection{Immunofluorescence Staining}

K562 cells or MDA-MB-231 cells were seeded into 6-well plates and then treated with vehicle control $0.1 \%$ DMSO, 16f $(10,20,40 \mathrm{nM})$ or 16f $(20,40,80 \mathrm{nM})$ respectively. The cells were fixed with $4 \%$ paraformaldehyde and then penetrated with PBS for three times. After blocking for $20 \mathrm{~min}$ by adding 50-100 $\mu \mathrm{L}$ goat serum albumin at room temperature, cells were incubated with a monoclonal antibody (anti- $\alpha$-tubulin) at $37^{\circ} \mathrm{C}$ for $2 \mathrm{~h}$. Then the cells were washed three times by PBS following staining by fluorescence antibody and labeling of nuclei by 4,6-diamidino-2-phenylindole (DAPI). Cells were finally visualized using an LSM 570 laser confocal microscope (Carl Zeiss, Germany).

\subsubsection{Cell cycle analysis}

K562 cells were seeded into 6-well plates and incubated at $37{ }^{\circ} \mathrm{C}$ in a humidified $5 \%$ 
$\mathrm{CO}_{2}$ incubator for $24 \mathrm{~h}$, and then treated with or without $\mathbf{1 6 f}$ at indicated concentrations for another $48 \mathrm{~h}$. The collected cells were fixed by adding $70 \%$ ethanol at $4{ }^{\circ} \mathrm{C}$ for 12 h. Subsequently, the cells were resuspended in PBS containing $100 \mathrm{~mL}$ RNase A and $400 \mathrm{~mL}$ of propidium iodide for $30 \mathrm{~min}$. The DNA content of the cells was measured using a FACS Calibur flow cytometer (Bectone Dickinson, San Jose, CA, USA).

\subsubsection{Cell apoptosis analysis}

After treatment with or without $\mathbf{1 6 f}$ at indicated concentrations for $48 \mathrm{~h}$, the cells were washed twice in PBS, centrifuged and resuspended in $500 \mathrm{~mL}$ AnnexinV binding buffer. The cells were then harvested, washed and stained with $5 \mathrm{~mL}$ Annexin V-APC and $5 \mathrm{~mL}$ 7-AAD in the darkness for $15 \mathrm{~min}$. Apoptosis was analyzed using a FACS Calibur flow cytometer (Bectone Dickinson, San Jose, CA, USA).

\subsubsection{Mitochondrial Membrane Potential Analysis}

After treatment with vehicle control 0.1\% DMSO, 16f $(10 \mathrm{nM}, 20 \mathrm{nM}$, and $40 \mathrm{nM})$ for $24 \mathrm{~h}$, the cells were washed in PBS and resuspended in $500 \mathrm{~mL} \mathrm{JC}-1$ incubation buffer at $37{ }^{\circ} \mathrm{C}$ for $15 \mathrm{~min}$. The percentage of cells with healthy or collapsed mitochondrial membrane potentials was monitored by flow cytometry analysis (Bectone-Dickinson, San Jose, CA, USA).

\subsubsection{Wound healing assay}

K562 cells were grown in 6-well plates for $24 \mathrm{~h}$. Scratches were made in confluent monolayers using $200 \mu \mathrm{L}$ pipette tip. Then, wounds were washed twice with PBS to remove non-adherent cell debris. The media containing different concentrations $(1,2$, $4 \mathrm{nM}$ ) of the compound $\mathbf{1 6 f}$ were added to the petridishes. Cells which migrated across the wound area were photographed using phase contrast microscopy at $0 \mathrm{~h}$ and $24 \mathrm{~h}$. The migration distance of cells migrated in to the wound area was measured manually.

\subsubsection{Tube formation assay}

EC Matrigel matrix was thawed at $4{ }^{\circ} \mathrm{C}$ overnight, and HUVECs suspended in 
DMEM were seeded in 96-well culture plates at a cell density of 50,000 cells/well after polymerization of the Matrigel at $37^{\circ} \mathrm{C}$ for $30 \mathrm{~min}$. They were then treated with $20 \mu \mathrm{L}$ different concentrations of compound $\mathbf{1 6 f}$ or vehicle for $6 \mathrm{~h}$ at $37{ }^{\circ} \mathrm{C}$. Then, the morphological changes of the cells and tubes formed were observed and photographed under inverted microscope (OLYMPUS, Japan).

\subsubsection{In vivo antitumor evaluation}

Five-week-old male Institute of Cancer Research (ICR) mice were purchased from Shanghai SLAC Laboratory Animals Co. Ltd. A total of $1 \times 10^{6} \mathrm{H} 22$ cells were subcutaneously inoculated into the right flank of ICR mice according to protocols of tumor transplant research, to initiate tumor growth. After incubation for one day, mice were weighted and at random divided into eight groups of eight animals. The groups treated with $\mathbf{1 6 f}$ was administered 10, $20 \mathrm{mg} / \mathrm{kg}$ in a vehicle of $10 \% \mathrm{DMF} / 2 \%$ Tween 80/88\% saline, respectively. The positive control group was treated with PTX (6 mg/kg) every 2 days by intravenous injection. CA-4 and CA-4P were administered $20 \mathrm{mg} / \mathrm{kg}$ in a vehicle of $10 \% \mathrm{DMF} / 2 \%$ Tween $80 / 88 \%$ saline and saline solution, respectively. The negative control group received a vehicle of $10 \% \mathrm{DMF} / 2 \%$ Tween $80 / 88 \%$ saline through intravenous injection. Treatments of 16f, CA-4 and CA-4P were done at a frequency of intravenous injection one dose per day for a total 21 consecutive days while the positive group was treated with PTX one dose per two days. The mice were sacrificed after the treatments and the tumors were excised and weighed. The inhibition rate was calculated as follows: Tumor inhibitory ratio $(\%)=(1$-average tumor weight of treated group/average tumor weight of control group) $\times 100 \%$.

\subsection{Molecular modeling}

In our study, the X-ray structure of the DMDA-colchicine- $\alpha, \beta$-tubulin complex was downloaded from the Protein Data Bank (PDB code 5lyj). The protein was prepared by removal of the stathmin-like domain, subunits $\mathrm{C}$ and $\mathrm{D}$, water molecules and colchicine using Discovery Studio modules. The docking procedure was performed by employing DOCK program in Discovery Studio 3.0 software, and the structural image was 
obtained using PyMOL software.

\section{Acknowledgments}

This study was supported from the National Natural Science Foundation of China (nos. 81673306, 81703348), The Open Project of State Key Laboratory of Natural Medicines, China Pharmaceutical University (no. SKLNMKF 201710), China Postdoctoral Science Foundation (no. 2017100424) for financial support, and "Double First-Class" University project CPU2018GY04, China Pharmaceutical University

\section{Reference}

[1] J. Howard, A. Hyman, Dynamics and mechanics of the microtubule plus end, Nat. 422 (2003) 753-758.

[2] M. Jordan, L. Wilson, Microtubules as a target for anticancer drugs, Nat. Rev. Canc. 4 (2004) 253-265.

[3] C. Dumontet, M. Jordan, Microtubule-binding agents: a dynamic field of cancer therapeutics, Nat. Rev. Drug Discov. 9 (2010) 790-803.

[4] E. Porcù, R. Bortolozzi, G. Basso, G. Viola, Recent advances in vascular disrupting agents in cancer therapy, Future Med. Chem. 6 (2014) 1485-1498.

[5] S. Guggilapu, L. Guntuku, T. Reddy, A. Nagarsenkar, D. Sigalapalli, V.G.M. Naidu, S.K. Bhargava, N. Bathini, Synthesis of thiazole linked indolyl-3-glyoxylamide derivatives as tubulin polymerization inhibitors, Eur. J. Med. Chem. 138 (2017) 83-95. [6] G. R. Pettit, S. B. Singh, M. R. Boyd, E. Hamel, R. K. Pettit, J. M. Schmidt, F. Hogan, Antineoplastic agents. 291. isolation and synthesis of combretastatins A-4, A5, and A-6, J. Med. Chem. 38 (1995) 1666-1672.

[7] S. Ducki, R. Forrest, J. Hadfield, A. Kendall, N. Lawtence, A. McGowm, D. Rennison, Potent antimitotic and cell growth inhibitory properties of substituted chalcones, Bioorg. Med. Chem. Lett. 8 (1998) 1051-1056.

[8] R. Ravelli, B. Gigant, P. Curmi, I. Jourdan, S. Lachkar, A. SObel, M. Knossow, Insight into tubulin regulation from a complex with colchicine and a stathmin-like 
domain, Nature 428 (2004) 198-202.

[9] R. Gaspair, A. Prota, K. Bargsten, A. Cavalli, M. Steinmetz, Structural basis of cisand trans-combretastain binding to tubulin, Chem. 2 (2017) 102-113.

[10] W. Li, H. Sun, S.Xu, Z. Zhu, J. Xu, Tubulin inhibitors targeting the colchicine binding site: a perspective of privileged structures, Future Med. Chem. 9 (2017) 17651794.

[11] Z. Wang, J. Chen, J. Wang, S. Ahn, C. Li, M., Y. Li, V. Loveless, J. Dalton, D. Miller, W. Li, Novel tubulin polymerization inhibitors overcome multidrug resistance and reduce melanoma lung metastasis, Pharm. Res. 29 (2012), 3040-3052.

[12] Q. Yue, X. Liu, D. Guo, Microtubule-binding natural products for cancer therapy, Planta Med. 76 (2010) 1037-1043.

[13] X. Wu, Q. Wang, W. Li, Recent advances in heterocyclic tubulin inhibitors targeting the colchicine binding site, Anti-Cancer Agents Med. Chem. 16 (2016) $1325-1338$.

[14] M. Dong, F. Liu, H. Zhou, S. Zhai, B. Yan, Novel natural product- and privileged scaffold-based tubulin inhibitors targeting the colchicine binding site, Molecules 21 (2016) 1375-1483.

[15] Y. Pang, B. An, L. Lou, J. Zhang, J. Yan, L. Huang, X. Li, S. Yin, Design, synthesis, and biological evaluation of novel selenium-containing isocombretastains and phenstatins as antitumor agents, J. Med. Chem. 60 (2017) 7300-7314.

[16] Q. Wang, K. Arnest, Y. Wang, G. Kumar, D. Ma, H. Chen, Z. Wu, J. Yang, S. White, D. Miller, W. Li, Structural modification of the 3,4,5-trimethoxyphenyl moiety in the tubulin inhibitor VERU-111 leads to improve antiproliferative activities, J. Med. Chem. 61 (2018) 7877-7891.

[17] M.A. Soussi, O. Provot, G. Bernadat, J. Bignon, D. Desravines, J. Dubois, J.D. Brion, S. Messaoudi, M. Alami, IsoCombretaQuinazolines: potent cytotoxic agents with antitubulin activity, Chem. Med. Chem. 10 (2015) 1392-1402.

[18] I. Khelifi, T. Naret, D. Renko, A. Hamze, G. Bernadat, J. Bignon, C. Lenoir, J. Dubois, J. Brion, O.Provot, M. Alami, Design, synthesis and anticancer properties of ioscombretaquinolines as potent tubulin assembly inhibitors, Eur. J. Med. Chem. 127 
(2017) 1025-1034.

[19] S. Banerjee, K. Arnst, Y. Wang, G. Kumar, S. Deng, L. Yang, G. Li, J. Yang, S. White, W. Li, D. Miller, Heterocyclic-fused pyrimidines as novel tubulin polymerization inhibitors targeting the colchicine binding site: structural basis and antitumor efficacy, J. Med. Chem. 61 (2018) 1704-1718.

[20] W. Li, F. Xu, W. Shuai, H. Sun, H. Yao, S. Xu, H. Yao, Z. Zhu, D. Yang, Z. Chen, J. $\mathrm{Xu}$, Discovery of novel quinoline-chalcone derivatives as potent anti-tumor agents with microtubule polymerization Inhibitory Activity, J. Med. Chem. 62 (2019) 9931013.

[21] M. Wase, B. T. Worrell, J. Yu, Pd ${ }^{0} / \mathrm{PR} 3$ - catalyzed arylation of nicotinic and isonicotinic acid derivatives, Angew. Chem. Int. Ed. 49 (2010) 1275-1277.

[22] I. Bonzheim, B. Mankel, P. Klapthor, J. Schmidt, T. Hinrichsen, O. Wachter, F. Fend, L.Quintanilla-Martinez, CALR-mutated essential thrombocythemia evolving to chronic myeloid leukemia with coexistent CALR mutation and BCR-ABL translocation, Blood 125 (2015) 2309-2311.

[23] C. J. Bailey, J. L. Gross, A. Pieters, A. Bastien, J. F. List, Effect of dapagliflozin in patients with type 2 diabetes who have inadequate glycaemic control with metformin: a randomised, double-blind, placebo-controlled trial, Lancet 375 (2010) 2223-2233. [24] F. Liu, P. I. Boross, F. Wang, J. Tozser, J. M. Louis, R. W. Harrison, I. T. Weber, Kinetic, Stability, and structural changes in high-resolution crystal structures of HIV-1 protease with drug-resistant mutations L24I, I50V, and G73S, J. Mol. Biol. 354 (2005) 789-800.

[25] J. Wu, M. Zhang, D. Liu, Acalabrutinib (ACP-196): a selective second-generation BTK inhibitor, J. Hematol. Oncol. 9 (2016) 21-24.

[26] R. Kaur, G. Kaur, R. Gill, R. Soni, J. Bariwal, Recent developments in tubulin polymerization inhibitors: An overview, Eur. J. Med. Chem. 87 (2014) 89-124.

[27] W. Li, Y. Yin, H. Yao, W. Shuai, H. Sun, S. Xu, J. Liu, H. Yao, Z. Zhu, J. Xu, Discovery of novel vinyl sulfone derivatives as anti-tumor agents with microtubule polymerization inhibitory and vascular disrupting activities, Eur. J. Med. Chem. 157 (2018) 1068-1080. 
[28] W. Li, W. Shuai, F. Xu, H. Sun, S. Xu, H. Yao, J. Liu, H. Yao, Z. Zhu, J. Xu, Discovery of novel 4-Arylisochromenes as anticancer agents inhibiting tubulin polymerization, ACS Med. Chem. Lett. 9 (2018) 974-979.

[29] W. Li, Y. Yin, W. Shuai, F. Xu, H. Yao, J. Liu, K. Cheng, J. Xu, Z. Zhu, S. Xu, Discovery of novel quinazolines as potential anti-tubulin agents occupying three zones of colchicine domain, Bioorg. Chem. 83 (2019) 380-390.

[30] W. Li, W. Shuai, H. Sun, F. Xu, Y. Bi, J. Xu, C. Ma, H. Yao, Z. Zhu, S. Xu, Design, synthesis and biological evaluation of quinoline-indole derivatives as anti-tubulin agents targeting the colchicine binding site, Eur. J. Med. Chem. 163 (2019) 428-442. 